\title{
CONSEQUENCES OF LOWER OIL PRICES AND STRANDED ASSETS FOR RUSSIA'S SUSTAINABLE FISCAL STANCE ${ }^{\#}$
}

\author{
Aleksandra Malova* $^{*}$ and Frederick van der Ploeg ${ }^{* *}$
}

\begin{abstract}
Despite substantial oil and gas revenue Russia's fiscal stance is unsustainable. Under our benchmark assumptions the permanent-income rule requires a permanent tightening of the fiscal stance by $4.6 \%$-points of GDP. Delaying it by a decade implies that the fiscal stance needs to be tightened by a further $0.9 \%$-point. This benchmark optimal policy ensures that depletion of oil and gas wealth is matched by an equal increase in above-ground financial wealth. Its merits are highlighted by comparing it with the tougher alternative of the bird-in-hand rule and with projecting the current fiscal stance. If oil and gas revenue rises by a half due to higher prices or more discoveries, the fiscal stance needs to be tightened by only 3.2\%-points of GDP. However, if a large chunk of oil and gas has to be kept in the soil to meet international agreements to keep global warming below 2 degrees Celsius, the permanent transfer drops to $2.0 \%$ of GDP and the fiscal stance needs to be tightened by $5.5 \%$-points of GDP.
\end{abstract}

Keywords: managing oil and gas revenues, sustainable fiscal stance, permanent income rule, Hartwick rule, bird-in-hand rule, stranded assets

JEL codes: H20, H63, Q33

October 2016, Revised February 2017

\footnotetext{
\# We acknowledge support from the St. Petersburg State University Laboratory "Economic Performance and the Environment". We are grateful to Dina Lvova, Nadezhda Pakhomova and Partha Sen for their helpful comments.

*Malova: St. Petersburg State University, 7/9 Universitetskaya nab., St. Petersburg, 199034 Russia. Email: a.malova@spbu.ru

*** Corresponding author Van der Ploeg: OXCARRE, Department of Economics, University of Oxford, Oxford OX1 3 UQ, United Kingdom and St. Petersburg State University, 7/9 Universitetskaya nab., St. Petersburg, 199034 Russia. Email: rick.vanderploeg@economics.ox.ac.uk
} 


\section{Introduction}

Oil and gas windfalls and their anticipation have a large impact on the public finances of a country. If the windfall is used to boost public spending or (via handouts) to boost private spending, the resulting fiscal stance will be very sub-optimal because it means that substantial tightening of the fiscal stance has to occur in the future to ensure solvability. This volatility of the share of taxes in the national income is highly undesirable, both from a political and a public finance perspective. The often recommended permanent-income prescription based on the theory of tax smoothing (Barro, 1979) avoids this volatility. It requires that countries facing a future oil and gas windfall borrow in advance of the anticipated windfall, pay back and save during the windfall, and live of the interest on the accumulated assets after the windfall. If the oil and gas windfall is unanticipated, such countries should only borrow once they get new information on big oil and gas discoveries leading to an increase in future oil and gas revenue and thus to an increase in oil and gas wealth. The permanent-income hypothesis also implies that the celebrated Hartwick rule must hold. This rule states that all oil and gas revenue must be invested to transform the below-ground oil and gas wealth into above-ground financial or other assets (Hartwick, 1977).

The main contribution of this paper is to show what the permanent-income rule and the Hartwick rule imply for the optimal management of Russian oil and gas revenue. The fiscal stance under the permanent-income rule, called the sustainable or permanent fiscal stance for short, should be a fixed proportion of above- and below-ground assets, but this has not been the case in Russia. In fact, Russia has been depleting its oil and gas wealth without building sufficient financial assets above the ground. The size of Russian funds is approximately 11\% of GDP in 2015 (Ministry of Finance of the Russian Federation, 2016), which is less than similar funds in other oil- and gas-rich countries. ${ }^{1}$ During the last four years Russia has used its oil and gas revenues primarily to finance its budget deficit with almost none of it spent on investments. If this situation prolongs into the future, Russia risks squandering its oil and gas wealth without using this revenue to diversify and make structural reforms to put the economy on a sustainable growth path. Furthermore, by not having saved enough of the oil and gas

\footnotetext{
${ }^{1}$ In 2015 the Norwegian SWF was $226 \%$ of its GDP, Kuwait's fund was $519 \%$ of its GDP, and the UAE fund was 208\% of its GDP (IFSWF, 2015)
} 
windfall, substantial tightening of the fiscal stance is required to put the government finances on a sustainable path.

We therefore calculate the required tightening of the fiscal stance that is needed to avoid volatile shares of tax revenues in national income. We compare this permanent-income outcome for the fiscal stance and its implications for debt and asset management with when the future fiscal stance is projected from historical policies ${ }^{2}$ and alternatively also with the more conservative bird-in-hand rule which states that oil and gas windfalls are saved entirely and only part of accumulated financial wealth is spent (e.g., Davis et al., 2002; Barnett and Ossowski, 2003; Medas and Zakharova, 2009; Harding and van der Ploeg, 2013). ${ }^{3}$

Given the current low oil and gas prices, we calculate that the required tightening of the fiscal stance is $4.6 \%$-points of GDP. If the future oil and gas prices or reserves turn out to be $50 \%$ higher, the required tightening is only 3.2\%-points of GDP. More important from a risk assessment point of view, we calculate by how much the required fiscal stance in Russia has to be further tightened if the international agreements made at the 2015 United Nations Climate Change Conference in Paris to limit peak global warming to 2 degrees Celsius are held up. Recent calculations suggest that this implies that $19 \%$ of Russia's oil reserves and 59\% of its gas reserves cannot be burnt and must be left in the ground (McGlade and Ekins, 2015). ${ }^{4}$ Our calculations suggest that the required tightening of the fiscal stance must then be much higher: 5.5\%-points of GDP.

Section 2 sets out the permanent-income rule and Hartwick rule for managing an oil and gas windfall and compares these with the bird-in-hand rule. Section 3 discusses historical developments of Russian oil and gas revenues and fiscal policy and the

\footnotetext{
${ }^{2}$ Ossowski et al. (2008) and Bornhorst et al. (2009) offer estimates of fiscal rules and discuss the sustainability of fiscal stances for oil-rich countries, Mendoza and Ostry (2008) do the same for emerging and industrial economies, and Ghosh et al. (2011) for advanced economies (e.g., Ghosh et al., 2011). These studies offer cross-country estimates, which makes them less appropriate for discussing intertemporal issues of managing oil windfalls. Harding and van der Ploeg (2013) therefore offer timeseries estimates of forward-looking fiscal rules for Norway.

${ }^{3}$ Norway uses such a pragmatic rule. It puts its oil and gas revenue in its fund and draws roughly 4 percent per annum from it to finance public spending or tax cuts. This 4-percent rule allows Norway to spread oil and gas revenues to future generations. The fund also allows Norway to stabilise the economy across the business cycle, since the $4 \%$ has to hold as an average over the business cycle.

${ }^{4}$ Carbon Tracker and Grantham Institute (2013) discuss the issue of unburnable carbon and stranded assets in much more detail. Helm (2016) and van der Ploeg (2016) discuss various other reasons to do with technological developments why the fossil fuel era may come to an end and why oil and gas rich countries face the risk of stranded oil and gas assets.
} 
various data issues that had to be faced. Section 4 shows by how much Russia's fiscal stance has to be tightened under the permanent-income rule for our benchmark scenario where the world oil price stays low, and also by how much more if the adjustment is delayed. The outcomes are compared with a projected historical fiscal rule and the birdin-hand rule. Section 5 shows by how much the sustainable fiscal stance is cut when the world oil price bounces back by $50 \%$ and by how much it needs to be increased when global warming has to be limited to 2 degrees Celsius. Section 5 also discusses the sensitivity of the results with respect to the return on assets. Section 6 discusses why and how the permanent-income rule needs to be adjusted to allow for capital scarcity and difficulties in borrowing on international capital markets and for temporary absorption constraints in the production of non-tradables. It also comments on short-run issues to do with exchange rate management and monetary policy. Section 7 concludes.

\section{Theory of managing oil and gas wealth and the fiscal stance ${ }^{5}$}

In this section we first outline the optimal fiscal policy and management based on the permanent income hypothesis and then contrast it with the bird-in-hand rule used in Norway. We also discuss what these rules imply for the management of a special oil and gas account or sovereign wealth fund. This allows us to demonstrate that the permanent-income rule is in accordance with the Hartwick rule, but that the bird-inhand rule is not.

\subsection{The permanent-income rule}

Let $a_{t}$ denote net government assets (gross assets minus liabilities) as fraction of national income at the end of period $t, g_{t}$ primary government spending (excluding net interest payments) as fraction of national income, $\tau_{t}$ the non-oil/gas tax rate, and $n_{t}$ oil

\footnotetext{
${ }^{5}$ A more general framework would make public spending endogenous and analyse the trade-off between using windfalls to boost public spending or cut tax rates and allow for a non-oil/gas tax base that depends on the business cycle by including the effects of an output gap in the government budget constraint (Harding and van der Ploeg, 2013). Allowing for habit persistence implies that society gets hooked on high public and private consumption during a windfall, but finds it tough to cut consumption after the windfall has ceased (Leigh and Olters, 2006; Olters, 2007). If habits last forever, the non-oil/gas primary deficit follows a random walk if public spending does not change. One can also allow for stochastic volatility of the oil price (van den Bremer and van der Ploeg, 2013, 2016). The prudence motive then requires building a stabilisation fund to accumulate precautionary saving buffers needed to cope with the volatile oil price and other uncertainties to do with oil and gas discoveries and the macro-economy.
} 
and gas revenue accruing to the government as fraction of national income in period $t$. The government budget constraint is

$$
a_{t+1}=(1+r) a_{t}+\tau_{t}+n_{t}-g_{t}=(1+r) a_{t}+n_{t}-p_{t},
$$

where $a_{0}$ is given and $p_{t} \equiv g_{t}-\tau_{t}$ denotes the primary non-oil/gas deficit. Since variables are expressed as fractions of national income, we use the growth-corrected real rate of interest, denoted by $r$, in (1). For simplicity, we take $r$ to be a constant. If we assume that the no-Ponzi games condition holds (i.e., we assume $\lim _{s \rightarrow \infty} a_{t+s}(1+r)^{-s}=0$ ) which amounts to solvency of the public sector, the present value of future oil and gas revenues plus government assets must be sufficient to cover the present value of future non-oil/gas primary deficits, $p_{t}$, Hence, the government budget constraint is given by

$$
\sum_{s=0}^{\infty}(1+r)^{-s} n_{t+s}+(1+r) a_{t} \geq \sum_{s=0}^{\infty}(1+r)^{-s} p_{t+s}
$$

The government minimizes expected present discounted intertemporal tax distortions,

$$
E\left[\sum_{s=0}^{\infty} \beta^{-s} \tau_{t+s}^{2} \mid I_{t}\right]
$$

subject to the budget constraints (1) and (2), where $I_{t}$ is all information available at time $t$ which can be used to forecast the future values of taxes as share of national income. The rate of time preference is set to the growth-corrected real interest rate so that $0<\beta$ $=1 /(1+r)<1$ and government spending and oil and gas revenue as fractions of national income are taken to be exogenous. Intertemporal minimization implies that the marginal cost of fund is the same for all future time periods, and thus that all expected future tax rates must equal the current tax rate:

$$
E\left[\tau_{t+s} \mid I_{t}\right]=\tau_{t} \text { for all } s>0
$$

This is what is meant by intertemporal tax smoothing. Tax rates can change in the future, but only upon news of unexpected changes in the government budgets (e.g., unexpected budgetary headwind due to an unexpected recession or unexpected oil and gas discoveries). Substituting the efficiency condition (4) into the intertemporal government budget constraint (2), we obtain the optimal tax rate as implied by the PIH, 
the optimal non-oil/gas primary deficit as fraction of national income, and the change in net government assets as fraction of national income:

$$
\tau_{t}=g_{t}^{P}-n_{t}^{P}-r a_{t}
$$

$$
p_{t}=g_{t}-g_{t}^{P}+r a_{t}+n_{t}^{P}
$$

$$
a_{t+1}-a_{t}=\left(n_{t}-n_{t}^{P}\right)-\left(g_{t}-g_{t}^{P}\right)
$$

where permanent oil and gas revenue (annuity value of current and future oil and gas revenue) and the permanent government spending share are defined by

$$
n_{t}^{P} \equiv \frac{r}{1+r}\left(n_{t}+\sum_{s=1}^{\infty}(1+r)^{-s} E\left[n_{t+s} \mid I_{t}\right)\right) \text { and } g_{t}^{P} \equiv \frac{r}{1+r}\left(g_{t}+\sum_{s=1}^{\infty}(1+r)^{-s} E\left[g_{t+s} \mid I_{t}\right)\right) \text {. }
$$

Permanent oil and gas revenue thus corresponds to the return on oil and gas wealth in the ground: $n_{t}^{P}=r v_{t}$ with oil and gas wealth defined by

$v_{t} \equiv \frac{1}{1+r}\left(n_{t}+\sum_{s=1}^{\infty}(1+r)^{-s} E\left[n_{t+s} \mid I_{t}\right)\right)$. Oil and gas wealth is thus the present discounted value of present and future oil and gas revenue. The permanent government spending share is that share that gives the same present discounted value as the projected government spending share.

Let us now interpret the optimal permanent-income rules (5)-(7). These can be viewed as rules which map the policy instruments (tax share, non-oil/gas primary deficit, public spending share, and the mutation in net government asset share) to the state variable (last year's ratio of net government assets to GDP) and exogenous variables (i.e., current and permanent values of oil and gas revenue and public spending shares). Since public spending is exogenous, solvency must be attained by variations in tax rather than spending shares. The rules give these insights.

First, equation (5) shows that the (non-oil/gas) tax rate can be lowered in response to permanent increase in oil and gas revenues but must be increased in response to permanent increases in the national income share of government spending. The tax rate also has to be higher if the inherited stock of net government assets is low (e.g., if the government debt is high). 
Second, equation (6) indicates that the non-oil/gas primary government deficit must be loosened if government spending is temporarily high as will be the case during a crisis or war. The optimal response is then to borrow, not to raise taxes. Equation (6) also indicates that the non-oil/gas primary fiscal stance can be looser if the permanent value of oil and gas revenue is high and inherited net government assets are high.

Third, equation (7) indicates that if current government spending is below projected future spending (e.g., due to greying of the population), the country should save more to provide for these future commitments. If due to a crisis or a war spending is high relative to projected future spending, the country should borrow. Also, if oil and gas revenue is expected to decline in the future, the permanent oil and gas revenue is below current revenue and therefore the country should save a part of its oil and gas revenue to smooth intertemporal tax distortions and avoid future tax hikes to ensure government solvency. If oil and gas revenue is expected to increase in the future, the country should borrow on international capital markets. Note that a high net government debt in itself does not warrant debt reduction as the required temporary tax hikes and spending cuts violate intertemporal tax and consumption smoothing.

To get further insight into the permanent-income rule, we note that the definition of oil and gas wealth implies that $v_{t+1}=(1+r) v_{t}-n_{t}$. Adding this to equation (7) and using $n_{t}^{P}=r v_{t}$, we see that the change in the sum of above- and below-ground assets is

$$
\left(a_{t+1}+v_{t+1}\right)-\left(a_{t}+v_{t}\right)=g_{t}^{P}-g_{t} .
$$

With constant levels of public spending, equation (9) indicates that total above-ground financial assets plus below-ground oil and gas wealth must thus be constant if the country pursues a permanent-income rule. As below-ground reserves are depleted, falling oil and gas wealth is thus gradually replaced by financial non-oil/gas assets. The size of the accumulated financial assets at the end of the windfall should thus exactly equal the permanent value of the stream of oil and gas revenue evaluated at the start when the news of the future windfall becomes known. The interest on the steady-state size of accumulated financial assets as fraction of national income after the windfall has ceased is just sufficient to finance the primary non-oil/gas deficit. This allows the hike in public and private consumption to be sustained after the windfall has ceased. Equation (9) shows that, if government spending is expected to rise over time, total 
below- and above-ground wealth must rise over time to provide for the future spending hike.

\subsection{Special oil and gas account or sovereign wealth fund}

Let us now see what happens if the country puts all the revenue from the oil and gas windfall into a special account. This oil and gas account can be a sovereign wealth fund, but can also be interpreted as a fictional oil and gas account. We will refer to it as a fund from now on. The stock of financial assets in this fund as fraction of national income at time $t$ is denoted by $f_{t}$. Other government assets at time $t$ are denoted by $b_{t}$, so that $a_{t}=b_{t}+f_{t}$. The disaggregated budget constraints of the oil and gas fund and the government are thus given by

$$
f_{t+1}=(1+r) f_{t}+n_{t}-z_{t} \text { and } b_{t+1}=(1+r) b_{t}+z_{t}+\tau_{t}-g_{t} \text {. }
$$

Under the permanent-income rule the amount that can be taken out of the oil and gas fund for purposes of the general budget at time $t$ is $z_{t}=n_{t}^{P}+r f_{t}=r\left(v_{t}+f_{t}\right)$. Hence, the dynamics of the special oil and gas account or sovereign wealth fund under the permanent-income rule is

$$
f_{t+1}-f_{t}=n_{t}-n_{t}^{P}
$$

Temporary boosts to oil and gas revenue are thus saved whilst permanent increases are used for the general government budget. Adding equation (10) to equation (7) and using $n_{t}^{P}=r v_{t}$, we get

$$
f_{t+1}+v_{t+1}=f_{t}+v_{t}
$$

Equation (12) is the celebrated Hartwick rule, which states that any running down of below-ground of oil and gas wealth must be exactly compensated by an equal increase of financial assets in the above-ground oil and gas fund (Hartwick, 1977). If the windfall starts at time 0 and ceases at time $T$, we thus $f_{0}=v_{T}=0$ and therefore $v_{0}=f_{T}$. At the start and at the end of the windfall the contribution to the general budget is the same, i.e., $z_{0}=z_{T}=r v_{0}=r f_{T}$, After the windfall has ceases, the sustained increase in the contribution to the general government budget is permanently financed out of interest on the accumulated financial assets in the fund. 
Note that the oil and gas fund can be a veil from a macro point of view. If Ricardian debt neutrality holds, private people will see through it and will realize that the oil and gas revenue eventually has to be handed to the private sector or spent by the government. By judicious use of capital markets, private agents can thus borrow against these inevitable future handouts. In practice, the government has much better access to capital markets than private agents. It may therefore be not so bad to assume that households are liquidity constrained and hand-to-mouth consumers and that the government has perfect access to international capital markets.

\subsection{The bird-in-hand rule}

Norway has practised for many years a more pragmatic and conservative approach to managing their oil and gas revenue. Basically, it amounts to not using any of the future oil and gas revenue and thus not to use future oil and gas revenue as collateral to borrow. Instead, Norway has adopted a bird-in-hand rule which states that all windfall revenue is put into a separate and independently managed fund and that only a fraction is allowed to be taken out of this fund each year towards the general budget. With such a rule the government thus does not borrow against future windfalls or respond to future needs such as a rising pension bill. The fraction that Norway has to withdraw from the fund is 4 percent, but this has become lower in recent years as Norway now has declining oil and gas revenue and has built up a sizeable fund already. The main difference with the permanent-income rule is that the fiscal stance now only reacts to above-ground financial wealth (i.e., the fund) and not to the total of below-ground oil and gas wealth and above-ground financial wealth.

Under the bird-in-hand rule the contribution to the general government budget at time $t$ is $z_{t}=0.04 f_{t} \cdot{ }^{6}$ The development of the oil and gas fund is then not given by (11) but by

$$
f_{t+1}=(1+r-0.04) f_{t}+n_{t}
$$

Since the bird-in-hand rule supposes that the government can or does not use future oil and gas revenue as collateral even if it anticipates higher oil and gas production sometime before the higher oil and gas revenue accrues, the fiscal stance does not react to oil and gas wealth or to $n^{P}$. Relative to the permanent-income rule, the bird-in-hand

\footnotetext{
${ }^{6}$ The bird-in-hand rule does not state how the increment in the non-oil budget deficit is divided into an incremental increase in public spending or a cut in taxes.
} 
rule implies that the transfer to the general government budget is too low (i.e., zero) ahead of the windfall, initially too high and then too high during the windfall, and finally eventually gradually falls back to its original level after the windfall (see Appendix B). The bird-in-hand rule thus leads to a much more volatile transfer from the SWF to the general government budget and thus violates principles of tax and consumption smoothing. This rule is therefore unhelpful if, for example, the pension burden is expected to rise. Since the growth-corrected return on financial assets, $r$, is empirically typically lower than $4 \%$, the fund as share of national income gradually falls to zero after the windfall (as the difference equation (13) is then stable).

Finally, note that the bird-in-hand rule does not say anything about what the share of taxes in national income should be. Of course, one would hope that a special oil and account fund and in particular an oil and gas fund that is independently managed would contribute to smoothing tax shares national income.

\section{Russian oil and gas revenue and fiscal policies ${ }^{7}$}

\subsection{From oil and gas extraction to oil and gas revenue}

Russia disposes significant amount of natural resources, especially hydrocarbons. The country has $6 \%$ of world proven oil reserves (102.4 billion barrels in 2015), similar to the United Arab Emirates (97.8 billion barrels) or Kuwait (101.5 billion barrels). Gas reserves in Russia account for $17.3 \%$ of world proven reserves (32.3 trillion cubic meters in 2015) and are roughly the same magnitude as those of Iran (34 trillion cubic meters) and slightly bigger than those of Qatar (24.25 trillion cubic meters) (BP, 2016). Further details on oil and gas revenue estimates are in Supplementary Appendix S.1.

To link reserves and revenues together, we suppose that there are no further discoveries of new oil fields and that the existing stock of oil is fully depleted at a constant rate in say 30 years as suggested by recent $\mathrm{R} / \mathrm{P}$ ratios for Russian oil reserves. Oil extraction in year $t$ is then $O I L_{t}=0.0333 R_{O I L}$, where ROIL $_{0}$ denotes initial oil reserves of 102.4 billion barrels (the value in 2015, BP 2016). Suppose that oil extraction costs are a fixed share of total revenues, which may be justified as suppliers of rigs capture part of the

\footnotetext{
${ }^{7}$ All the data we use is described in Appendix A
} 
scarcity rents on oil (e.g., Naumov and Toews, 2015). If government take is proportional to the oil price as suggested by the evidence (Stroebel and van Benthem, 2013), oil revenue in some future year $t$ equals $\alpha^{\text {OIL }} P_{t}^{O I L} O I L_{t}$, where $0<\alpha^{O I L}<1$ captures the combined effects of government take and extraction costs and $P_{t}^{\text {OIL }}$ is the world oil price in year $t$. Russian data suggests that a good figure for $\alpha^{\text {OIL }}$ is 0.6 . Furthermore, suppose that the best predictor of the future oil price is today's oil price as empirical evidence suggests that it is difficult to reject the hypothesis that the oil prices follows a random walk (Hamilton, 2009). Hence, oil revenue as fraction of national income in year $t$ is given by $n O I L_{t} \equiv 0.0333 \alpha^{O I L} P_{0}^{O I L} R^{O I L} L_{0} / G D P_{t}$, where $G D P_{t}$ denotes Russia's GDP at some future year $t>0$ and we take the initial oil price to be $\$ 40$ per barrel. With trend GDP growth of $\gamma$ per year, we use $n O I L_{t}=0.0333 \alpha^{\text {OIL }} P_{0}^{\text {OIL }} \operatorname{ROIL}_{0}(1+\gamma)^{-t} / G D P_{0}=(1+\gamma)^{-t} n O I L_{0}, \forall t>0$, to project windfall of oil revenue forwards with. ${ }^{8}$ We can also use this expression to perform a sensitivity exercise for an optimistic scenario where the future oil price is $\$ 60$ instead of $\$ 40$ dollar per barrel or where due to discoveries of new oil and gas fields reserves turn out to be $50 \%$ higher than reported today. In that case, oil revenue is given by $n O I L_{t}=1.5(1+\gamma)^{-t} n O I L_{0}, \forall t>0$, and declines with the rate of growth of the economy. We assume GDP growth of $\gamma=0.02$ per year.

Russia's gas reserves at end of year $t$ are denoted by $R G A S_{t}$ and gas extraction during year $t$ by $G A S_{t}$. The R/P ratio in years has hovered around 55.5 during 1998 to 2015, so gas lasts much longer than oil. Gas revenue as fraction of national income is thus $n G A S_{t}=0.018 \alpha^{G A S} P_{0}^{G A S} R G A S_{0}(1+\gamma)^{-t} / G D P_{0}=(1+\gamma)^{-t} n G A S_{0}, \forall t>0$. Russian data suggests to set $\alpha^{G A S}$ to $0.3, R G A S_{0}$ denotes initial gas reserves of 32.3 trillion cubic meters in 2015 (BP, 2016). Aggregate oil and gas revenue as fraction of GDP are defined as $n_{t} \equiv n O I L_{t}+n G A S_{t}$. With these assumptions figure 1 reports past and projected oil and gas revenue and the past trajectories of the world oil and gas price.

\footnotetext{
${ }^{8}$ If we assume that discoveries each year are a fraction $\beta$ of remaining reserves, then one can show that the share of oil revenue as fraction of GDP is, $n O I L_{t}=n O I L_{0}, \forall t>0$, if $\beta=\gamma$.
} 
First, we consider the benchmark scenario with an oil price of $\$ 40$ per barrel, a gas price of $\$ 200$ per thousand cubic meters, no additional discoveries of oil and gas, and no limitations to extraction volumes. Oil and gas revenue in Russia then constitute $7.3 \%$ of current GDP today to $3.9 \%$ of projected GDP in 2046 when oil reserves are going to be fully depleted. In 2047 there will be a sharp decline in hydrocarbon revenue down to $0.6 \%$ of projected GDP as it only comes from gas. After 2060 total oil and gas reserves are fully exhausted and revenue has dried up.

Figure 1: Oil and gas revenue - world prices and different projections
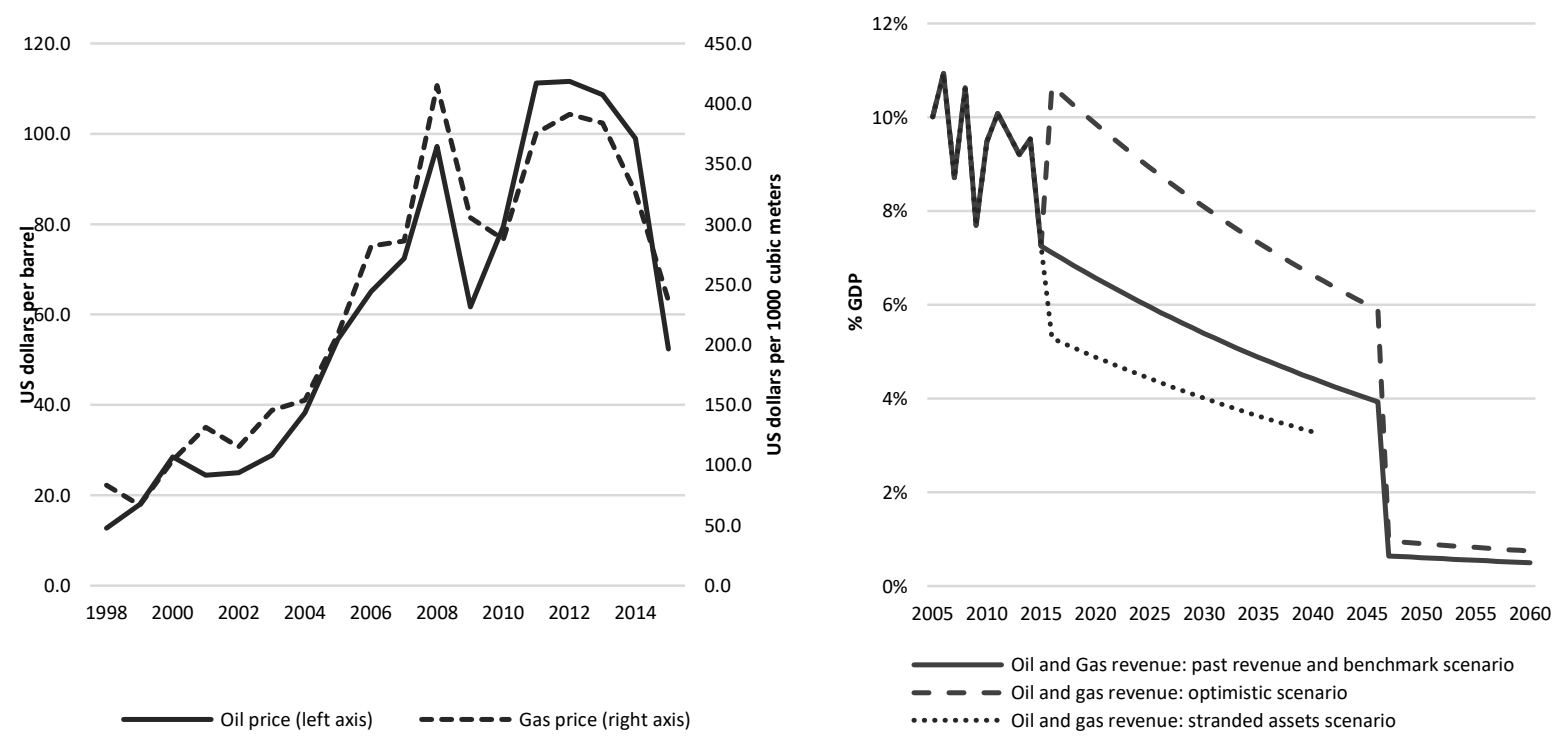

Source: Government Budget of Russian Federation (2005-2015), BP report 2014, authors' calculations (2016-2059)

Second, we analyse the optimistic scenario with 50\% higher prices, i.e., an oil price of $\$ 60$ per barrel and a gas price of $\$ 300$ per thousand cubic meters. This scenario also corresponds to the situation with additional discoveries leading to 50\% more reserves with oil and gas prices at benchmark levels. Oil and gas revenue received by the government now decline from 10.7\% of GDP in 2016 to $5.9 \%$ of GDP in 2046. The revenue under this optimistic scenario shrinks to 1\% of GDP after full oil reserves depletion and ceases by 2060 .

Third, we present a pessimistic scenario which takes place if Russia wants to meet international agreements to keep global warming below $2{ }^{\circ} \mathrm{C}$. Recent calculations suggest that this means that for Russia $19 \%$ of its oil reserves and $59 \%$ of its gas 
reserves cannot be burnt and must be left in the ground (McGlade and Ekins, 2015) ${ }^{9}$. In this case the permitted volume of oil and gas reserves will be depleted by 2040 . The oil and gas revenue shrinks to $5.3 \%$ of GDP in 2016 and is only $3.3 \%$ of GDP in 2040.

\subsection{Past fiscal policies and the funds}

Oil and gas revenue accounts for approximately $25 \%$ of general budget revenue. This share remains more or less constant since 2005, but revenue management has changed several times since 2005. During 2005-08 about half of oil and gas revenue was retained within oil and gas funds. The part of the revenue that was channeled to the government budget was spent on capital government expenditures too. The government thus accumulated within oil and gas funds approximately 16\% of GDP by the end of 2008 . From then on much less and eventually none of oil and gas revenue was saved in a fund. During 2009-10 almost half of accumulated funds since 2004 was used to mitigate the consequences of the world financial crisis of 2008. The period of 2011-13 was relatively untroubled and the government managed to save less than quarter of total oil and gas revenue and the remainder was directed to the budget. But after the Crimea conflict in 2014 and the ensuing sanctions all of oil and gas revenue was spent to finance the deficit. The situation was aggravated after the slump in oil prices of 2015. Starting from 2015 the government spends all oil and gas revenue to finance the budget deficit. Moreover, part of the oil and gas funds is used to ensure that the primary deficit hovers around zero. Supplementary Appendix S.2 discusses past fiscal policies and detailed description of oil and gas funds in the Russian economy.

\section{The permanent-income, delayed permanent-income and bird-in-hand rules}

To assess what the implications are of a permanent-income and a bird-in-hand rule for the management of Russia's oil and gas revenue windfall, we first as a benchmark project government spending and taxes as fraction of national income into the future from 2016 onwards. We then investigate what happens if the Russian government adopted a special oil and gas account or fund and uses a permanent-income rule and

\footnotetext{
${ }^{9}$ More than $90 \%$ of Russia's coal reserves must be left unburnt in the crust of the earth. This large fraction can be attributed to the high carbon content of coal. To the extent that Russia is unable to lock up most of its coal reserves, it will have to lock up even more of its oil and gas reserves to meet international targets to limit global warming
} 
compare the resulting outcomes for the optimal taxes, fiscal stance, assets and fund with those that would prevail under a continuation of existing policies. We then show that the required adjustment of the fiscal stance is larger if the transition from historical to permanent-income policies is delayed by a decade. Finally, we compare these outcomes with those that prevail under the bird-in-hand rule.

These policy exercises assume that general government spending stays at $35 \%$ of GDP and trend economic growth is $2 \%$ per annum, and under our benchmark assumptions of a world oil price of $\$ 40$ per barrel and gas price of $\$ 200$ per thousand cubic meters.

\subsection{Unsustainability of current fiscal policy}

Oil and gas revenues accruing to the government are used to financing the general budget deficit, so they are not saved in the Reserve Fund or National Welfare Fund. We project a continuation of this policy up to the year 2060. Let us first suppose that non-oil and gas government revenue remains stable at about $26 \%$ of GDP. The government then needs to spend net assets to finance the growing budget deficit. From the dotted line in the left panel of figure 2(a), we see that the primary oil and gas deficit is rising from $2 \%$ of GDP in 2016 to $8.4 \%$ of GDP in 2047 while oil and gas revenues are steadily falling over time from 7\% of GDP in 2016 and vanishes from 2047 onwards (dashed line). The right panel of figure 2(a) indicates that net assets are then fully exhausted by 2048 so the country starts running an ever-increasing debt and thus the fiscal stance is unsustainable.

Another way of looking it is to see what happens if the government each year tightens the fiscal stance by raising non-oil/gas revenue or cutting primary spending to balance the budget (i.e., $p_{t}=g_{t}-\tau_{t}=r a_{t}+n_{t}$ ). In that case, figure 2(b) shows that net assets of the country are unchanged at $90 \%$ of GDP but the fiscal stance has to be tightened from almost nothing to 3.3\%-points of GDP by 2047. When oil revenue ceases in 2047, the fiscal stance has to jump up to almost 7\%-points of GDP. The necessary cuts in spending or increases in non-oil/gas taxes associated with such a severe tightening may lead to social unrest and is therefore politically unlikely to be feasible. 
Figure 2: Unsustainable current fiscal policy

(a) Continuation of past fiscal stance
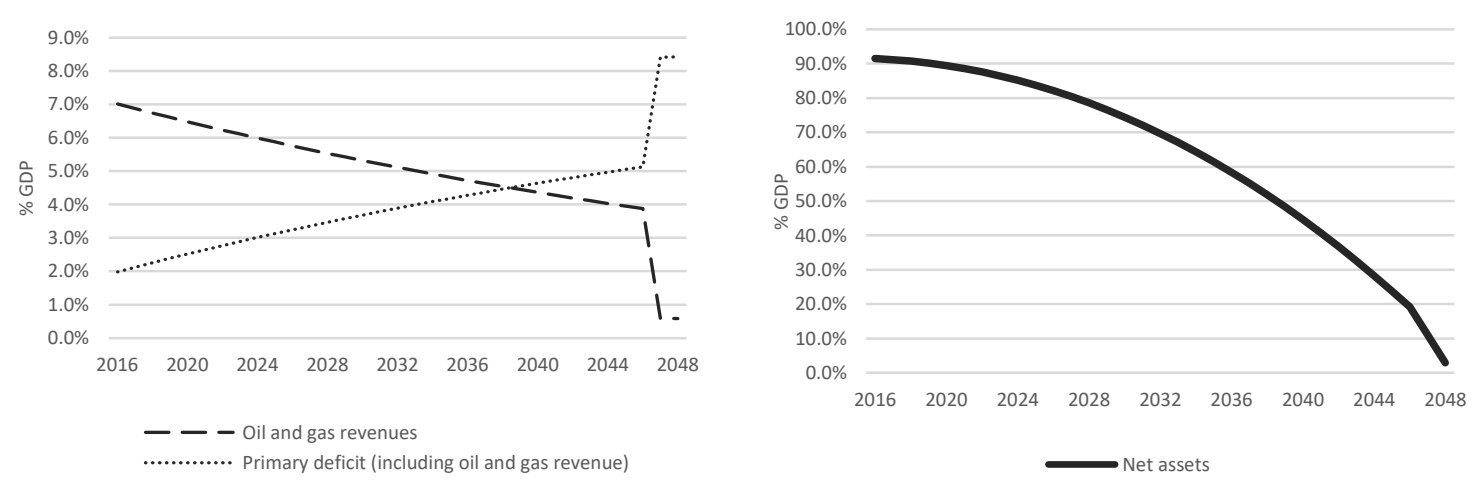

(b) Balanced budget with no change in net assets
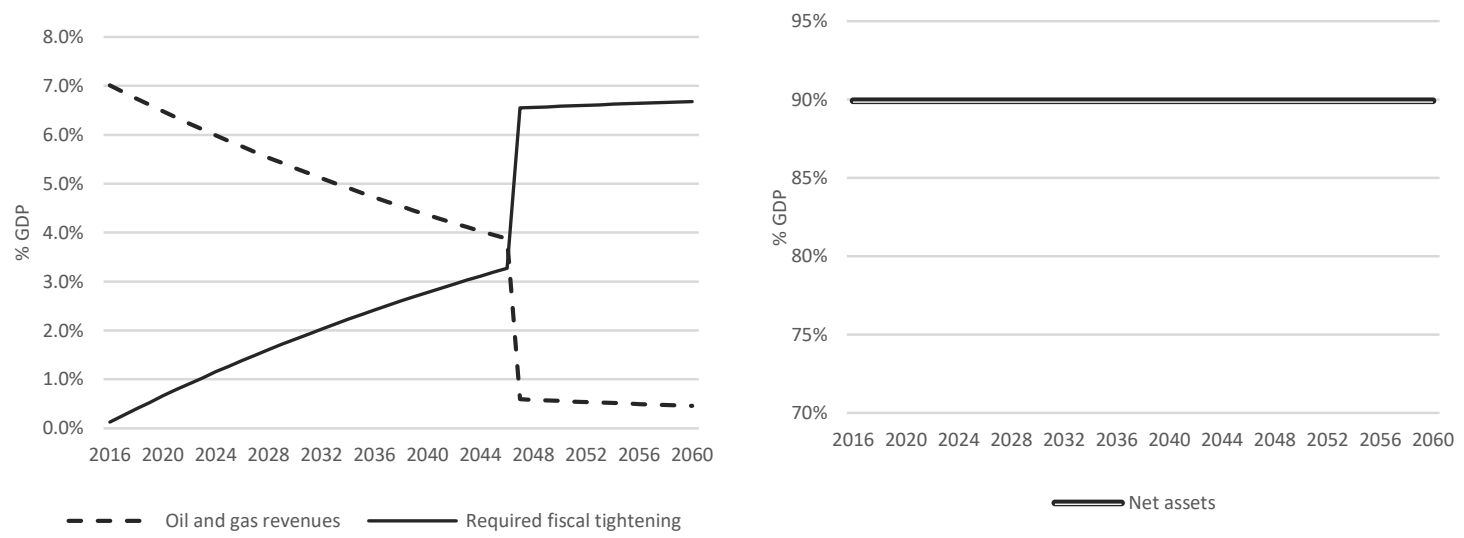

Source: authors' calculations

\subsection{Permanent-income rule and delayed permanent-income rule}

Figure 3(a) shows outcomes when the permanent-income rule is implemented from 2016 onwards. Despite declining oil and gas revenue, the budget transfer from oil and gas revenue is permanent and is a constant $2.9 \%$ of GDP (see the short-dashed line in the figure 3(a) left panel). Still, sustainability requires that the fiscal stance needs to be tightened by $4.6 \%$-points of GDP (solid line).

So non-oil and gas revenue has to increase to $30.6 \%$ from the current $26.1 \%$ of GDP unless primary spending is cut. This fiscal tightening happens only once at the start of the implementation of the permanent-income rule and after that non-oil and gas revenue is not increased. Although the required tightening is massive, this is not beyond the realms of possibilities as non-hydrocarbon revenue was about 35\% of GDP in 2005 and about $32 \%$ of GDP in 2007 . While oil and gas wealth in the ground is declining, oil and 
gas funds and net assets are growing. Net assets are projected to rise to more than two times GDP by 2060. Oil and gas funds are about three quarters of net assets.

Figure 3(b) plots the outcomes if the government for political or other reasons delays the adoption of the permanent-income rule by a decade. Non-oil and gas revenue then stay constant at $26.1 \%$ of GDP till 2025 at which point the government will implement the permanent-income rule.

\section{Figure 3: Outcomes under the permanent-income rule}

(a) Immediate implementation
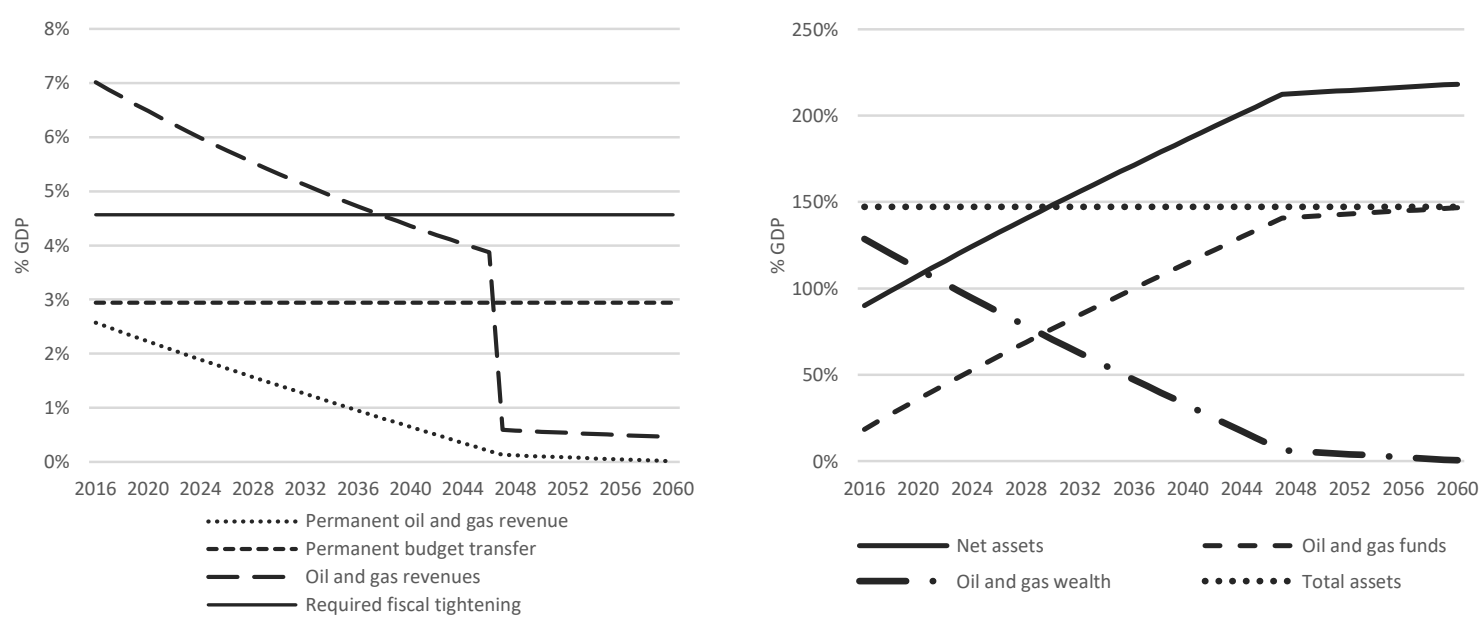

(b) Implementation delayed by ten years
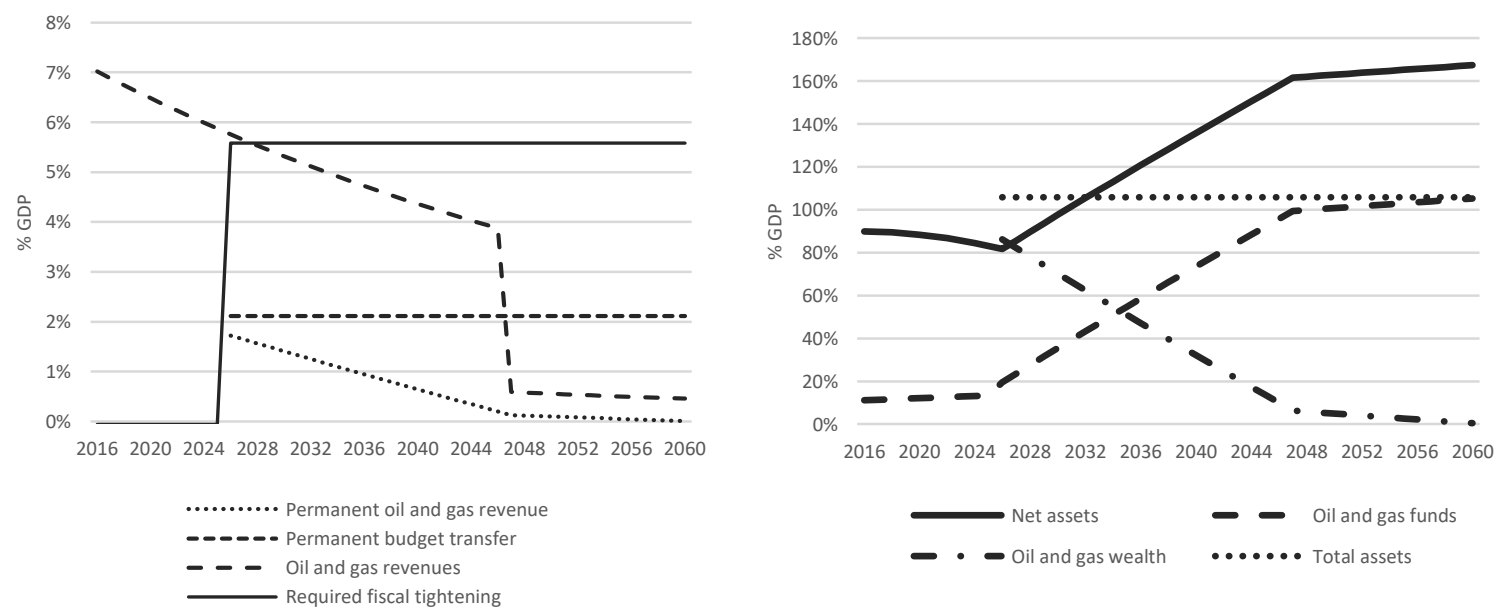

Source: authors' calculations

The permanent transfer to the general government budget from oil and gas revenue then amounts to $2.1 \%$ of GDP from 2025 (see the short-dashed line in the left panel). The fiscal stance needs to be tightened by 5.5\%-points of GDP. If primary spending is 
unchanged, non-oil and gas revenue thus has to be boosted from $26.1 \%$ to $31.6 \%$ of GDP in 2025. By delaying what is needed by a decade the fiscal stance has to be tightened by $0.9 \%$-point of GDP. Delaying the permanent-income rule implies that about 50\%-points of GDP less net assets will be accumulated by 2060, namely $167.5 \%$ of GDP (with oil and gas funds being about $105.3 \%$ of GDP).

\subsection{Bird-in-hand rule}

Figure 4 plots the outcomes under the bird-in-hand rule, which is a much more conservative fiscal policy for managing resource revenue. Under this rule the transfer to the general government budget from oil and gas revenue is volatile. It starts from $0.4 \%$ of GDP in 2016, reaches its high of 5\% of GDP in 2047, and slowly drops to $4.1 \%$ in 2060. Required fiscal tightening is volatile as well. Current non-oil and gas revenue needs to be boosted by a whacking 7\%-points of GDP to $33 \%$ of GDP if primary spending is assumed to be unchanged. After this sharp rise the required tightening falls slowly to $2.5 \%$ of GDP in 2047 and begins to grow up to $3.4 \%$ of GDP by 2060 . However, if we project further into the future, we see that in 2081 it reaches the value of $4.8 \%$ of GDP and keeps growing. Net assets grow until 2047. After 2047 oil and gas funds (part of net assets) slowly decline, so the growth of net assets tapers off as well.

\section{Figure 4: Outcomes under the bird-in-hand rule}
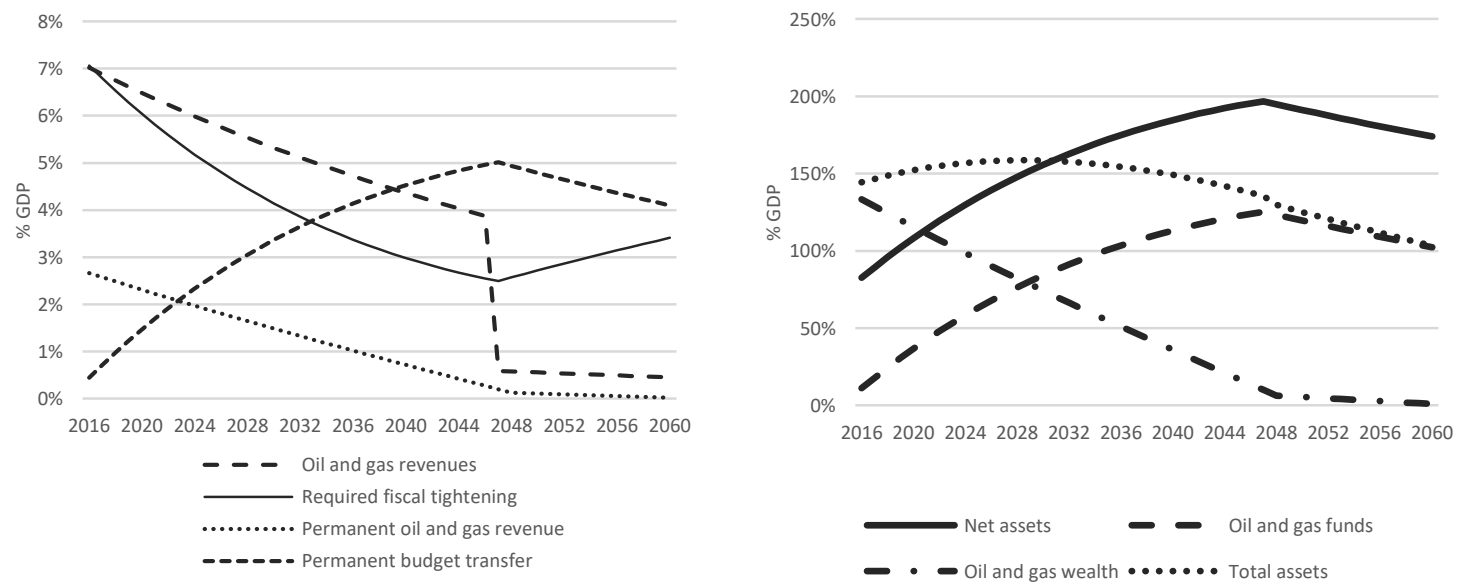

Source: authors' calculations

The bird-in-hand rule is sub-optimal. It does not minimize intertemporal tax distortions. Volatility of non-oil and gas revenue can have a negative impact on the political and economic situation of the country. Furthermore, if primary spending remains 
unchanged, the necessary jump in non-oil/gas revenue to $33 \%$ of GDP seems very tough indeed to achieve. Finally, the oil and gas wealth is not preserved within the oil and gas funds for the wealth of future generations under the bird-in hand rule. Assets in the fund will be fully depleted with long enough passage of time so that a permanent boost to public spending or a permanent cut in non-oil/gas taxes is infeasible.

\section{Robustness}

We now investigate how the tightening of the fiscal stance that is required if Russia wants to have a sustainable use of its oil and gas revenue is affected in an optimistic scenario with higher future oil prices or substantial future discoveries of new oil and gas fields and a pessimistic scenario where Russia keeps large fractions of its oil and gas wealth in the ground to meet internationally agreed targets for maximal global warming in sections 5.1 and 5.2, respectively. We also discuss the sensitivity of the results with respect to the interest rate in section 5.3.

\subsection{Optimistic scenario: higher future oil prices}

Figure 5 plots the permanent-income outcomes under an optimistic scenario in which the oil and gas price are 50\% higher (i.e., $\$ 60$ per barrel and $\$ 300$ per thousand cubic meters, respectively). This is equivalent to new oil and gas discoveries boosting current proved oil and gas reserves by $50 \%$. The permanent transfer of oil and gas revenues flowing into the general government budget now amount to $4.3 \%$ of GDP, so that the fiscal stance has to be tightened up by 3.2\%-points only. For example, if primary spending is not cut, non-oil/gas revenue only needs to be $29.3 \%$ rather than the current $26.1 \%$ of GDP. Net assets will grow to $285.3 \%$ of GDP by 2060 and oil and gas funds will grow to $214 \%$ of GDP.

No fiscal tightening under the permanent-income rule is required if oil and gas prices soar up to $\$ 100$ per barrel and $\$ 400$ per thousand cubic meters, respectively. In that case, the permanent budget transfer is $6.7 \%$ of GDP. Of course, this might be wishful thinking as oil and gas prices are unlikely to stay forever at such a high level (e.g., Helm, 2016, 2017). More likely is that oil and gas prices rocket temporarily up to these levels and then fall steadily back again at a rate of $10 \%$ per year. The permanent budget transfer will then be more than the $2.8 \%$ of GDP under the benchmark, namely $3.7 \%$ of 
GDP. As a result, the fiscal stance needs to be tightened by 3.8\%-points of GDP which is less than the required tightening of $4.6 \%$-points under the benchmark scenario.

Figure 5: Oil and gas prices bounce back by $50 \%$
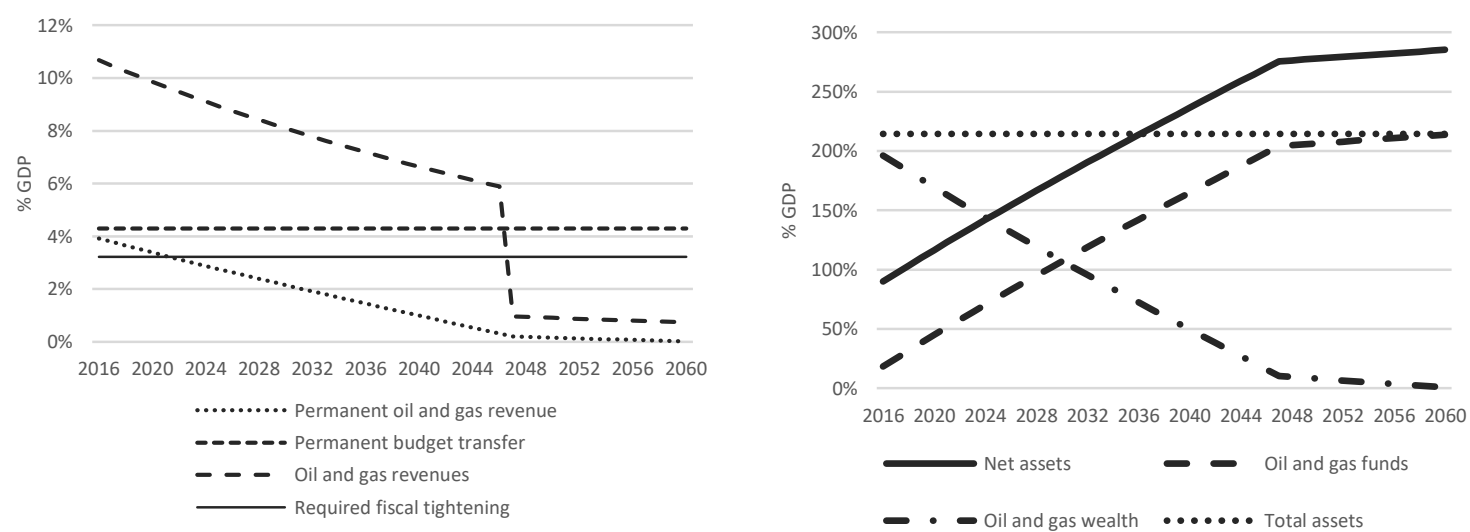

Source: authors' calculations

\subsection{Stranded carbon assets scenario}

Government leaders have agreed at the 2015 United Nations Climate Change

Conference in Paris to limit global warming to 2 degrees Celsius at most and aim for even less global warming (to 1.5 degrees Celsius). This is a big call. It implies that many of the world's carbon assets will be stranded and have to be left in the ground in order to limit cumulative carbon emissions and global warming. Those carbon assets with the highest carbon intensity such as the tar sands and coal will be most strongly affected. Also, carbon assets that are expensive to extract per unit of energy will be hit as well. Recent calculations suggest that this means that for Russia $19 \%$ of its oil reserves and 59\% of its gas reserves cannot be burnt and must be left in the ground (McGlade and Ekins, 2015). ${ }^{10}$ To assess the impact of meeting climate targets for Russia, we calculate by how much the required fiscal stance in Russia has to be further tightened if these large chunks of oil and gas reserves are indeed kept in the ground. Figure 6 plots outcomes under this pessimistic scenario.

Oil and gas reserves are fully depleted by 2040 . The permanent transfer to the general government budget from oil and gas revenues will now be only $2.0 \%$ of GDP, so that

\footnotetext{
${ }^{10}$ More than $90 \%$ of Russia's coal reserves must be left unburnt in the crust of the earth. This large fraction can be attributed to the high carbon content of coal. To the extent that Russia is unable to lock up most of its coal reserves, it will have to lock up even more of its oil and gas reserves to meet international targets to limit global warming.
} 
the required fiscal tightening is 5.5\%-points of GDP. If primary government spending as fraction of GDP remains at its current level, the non-oil and gas revenue should be $31.5 \%$ of GDP in this case. Net assets will rise to only $158,7 \%$ of GDP compared to about $218 \%$ of GDP in 2060 under the benchmark scenario.

Figure 6: Stranded carbon assets and the permanent-income rule
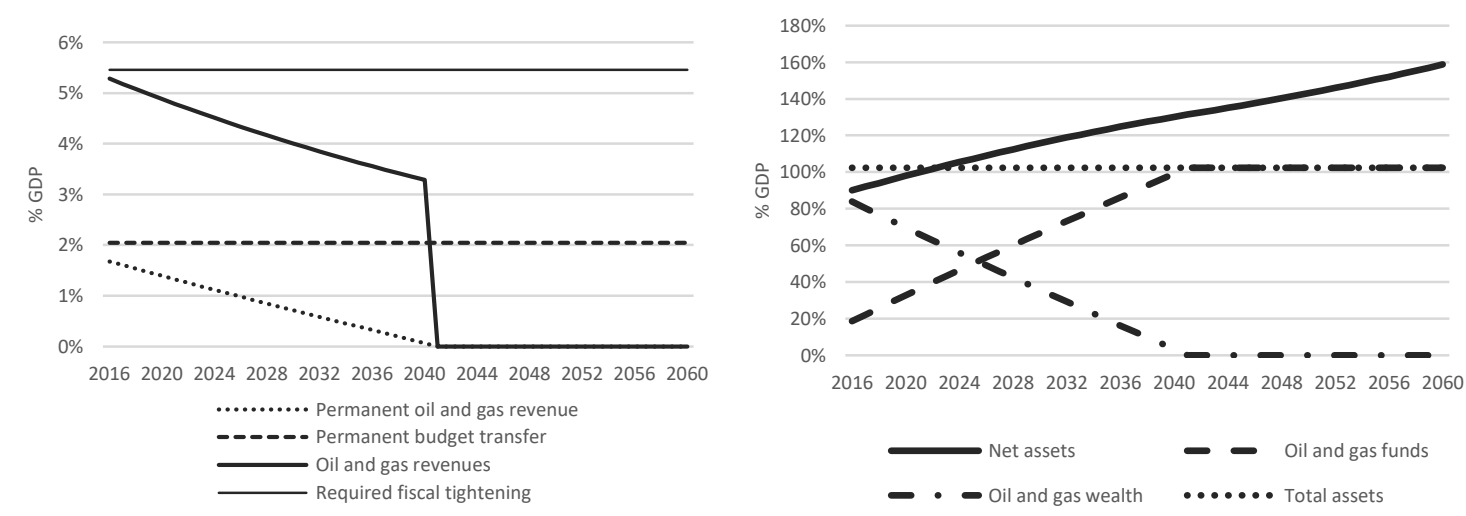

Source: authors' calculations

\subsection{Sensitivity of results to the real interest rate}

Our benchmark results discussed in section 4 and the results for the optimistic and pessimistic scenarios discussed here assume that the real interest rate is $2 \%$ per year. Table 1 reports the sensitivity of the required fiscal tightening, the permanent budget transfer and total assets to the real interest rate. The benchmark results for the permanent budget transfer were $2.9 \%$-points and a required fiscal tightening of $4.6 \%$ points of GDP, but if the real interest rate doubles to $4 \%$ per year the fund will generate more income and thus the required fiscal tightening is only 1.2\%-points of GDP and the permanent budget transfer can rise to $4.8 \%$-points. Due to the higher interest rate initial oil and gas wealth is depressed from 128.7 to $100.5 \%$ of GDP. The above-ground financial wealth in 2060 is thus $28 \%$-points of GDP lower. The sum of above- and below-ground assets (lower than the benchmark too) remains constant over time at $119 \%$ of GDP. Conversely, if the interest rate halves to a mere $1 \%$ per year, the budgetary challenges are much higher as can be seen from the required fiscal tightening having to be as much as $6.6 \%$-points of GDP whilst the permanent budget transfer that the fund can afford drops to 1.7\%-points of GDP. Initial oil and gas wealth is now 19\%points of GDP higher and consequently the total assets in the fund rise by 19\%-points of 
GDP by 2060; the sum of below- and above-ground wealth (higher than in the benchmark too) stays over time constant at $166 \%$ of GDP.

Our results for the optimistic high oil price and stranded assets scenarios discussed in sections 5.1 and 5.2 are also affected by the real interest rate. If the real interest rate turns out to be only $1 \%$ per year, the required fiscal tightening is $5.8 \%$-points in the optimistic scenario instead of 3.2\%-points of GDP in the benchmark scenario. However, with lower real returns on financial assets, in the stranded assets scenario fiscal tightening has to rise to 7.1\%-points and the permanent budget transfer that can be afforded drops from 2 to $1.1 \%$-points of GDP.

Table 1: Summary and sensitivity with respect to the interest rate

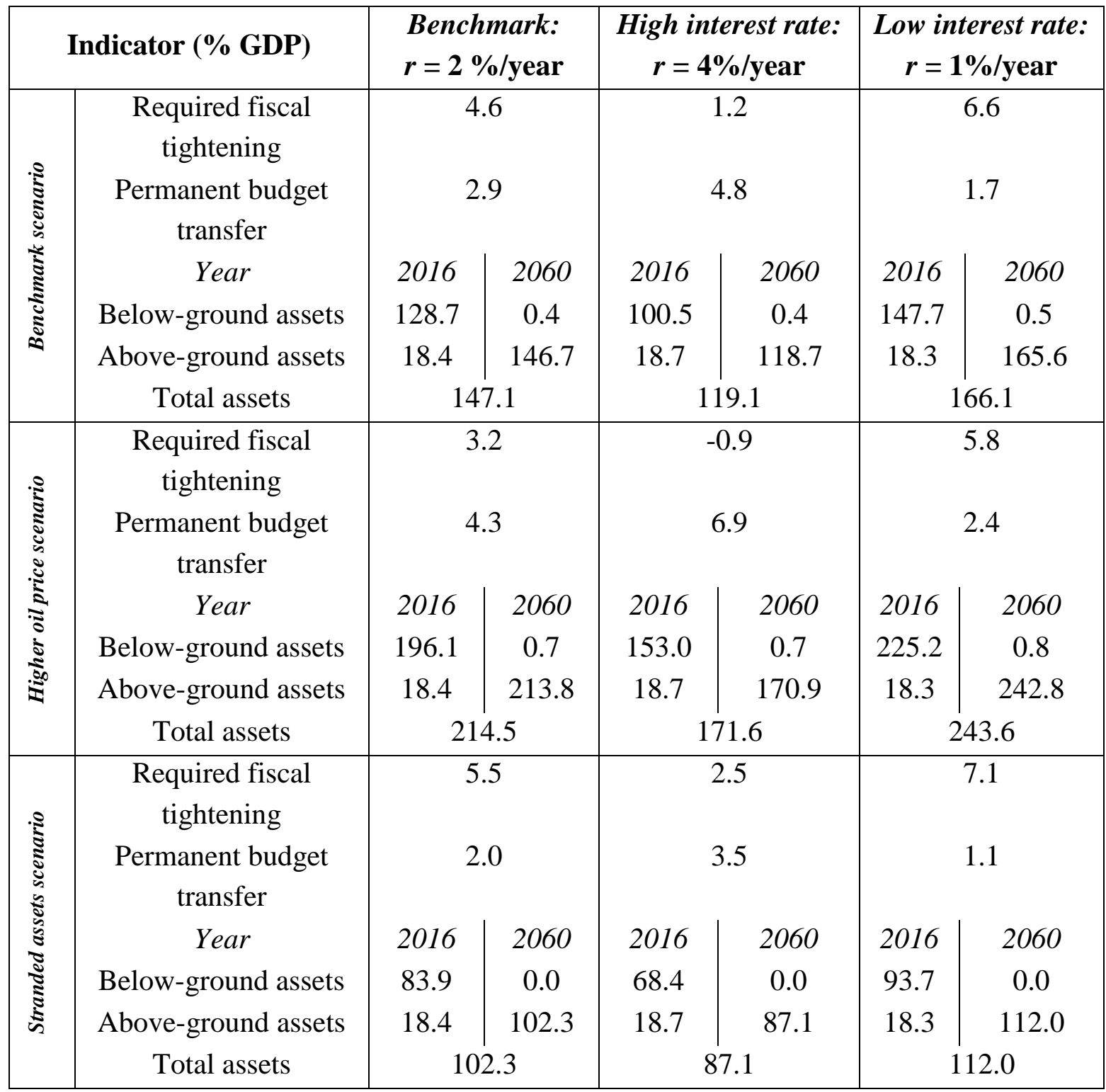




\section{Qualification and extensions}

The permanent-income rule discussed in section 2 and quantitatively applied to Russia in sections 4 and 5 needs to be extended in a number of directions to take account of some special features facing developing economies. First, many resource-rich developing economies face restricted access to international capital markets (as has been the case for Russia too). Their investments and productive capital are therefore sub-optimally low. Section 6.1 discusses how the permanent-income rule needs to be adjusted to deal with capital scarcity. Second, many such developing economies simply do not have the absorptive capacity to cope with the surge in demand for non-traded goods and services. Section 6.2 discusses how the optimal policy needs to be adjusted to allow for absorption constraints and Dutch disease phenomena, paying particular attention to the required movements of the real exchange rate that are needed to set in motion an "investing to invest" strategy. Third, in the short run wages and prices adjust sluggishly and monetary authorities have to pick up the pieces if the fiscal authorities fail to smooth the effects of the oil and gas windfall. Section 6.3 therefore discusses some issues relating to exchange rate regimes such as a nominal exchange rate peg, a float or a managed float.

\subsection{Capital scarcity and economic development}

In the framework developed in section 2 and applied in sections 4 and 5 it is not optimal to use any part of the oil and gas windfall for domestic investments (e.g., Collier et al., 2010; van der Ploeg and Venables, 2012). The reason is that if countries have perfect access to international capital markets they can finance themselves already any worthwhile investment for which the discounted value of future returns on investment exceeds the initial outlays. Investment should thus already be at its optimal level and the windfall does not change that. The fund should invest all its assets abroad on the global capital markets. However, if a country has insufficient access to capital to finance its investment needs as can be witnessed from significant spreads between domestic and world interest rates, there is capital scarcity and investments will be sub-optimally low. A windfall can and must then be used to alleviate capital scarcity, reduce debt and credit worthiness, boost investment, and boost growth and development (van der Ploeg and Venables, 2011, 2012; Agenor, 2016; Aurejo, et al., 2016). 
The permanent-income prescriptions discussed in sections 2, 4 and 5 are thus relevant for advanced oil- and gas-rich economies such as Norway, but may not be suitable for countries that have restricted access to international capital markets. One could argue that there have been phases during which the Russian economy experienced restricted access to international capital markets and therefore the permanent-income prescriptions serve as a useful benchmark but need adjustment to allow for capital scarcity.

First, as argued already, saving of the entire windfall is not optimal in countries with capital scarcity. Part of it must be invested in domestic public infrastructure such as roads, railways, schools and hospital. Such projects typically yield a higher return than saving it in the foreign assets; the return on investing in education of young girls in a developing country is typically many times higher than investing in US Treasury Bills. Agenor (2016) analyses resource revenue management policy for developing economies from internal stability point of view. His analysis confirms that the best policy for capital-scarce economies is to part save and part spend the windfall. How big these parts are depends on how much the government prefers to pay attention to curbing private consumption volatility and general macroeconomic volatility.

Second, current generations in developing countries suffer from relatively low income and consumption and hopefully future generations will benefit from resource-fueled growth and development and will be richer. It then is reasonable from an equity point of view to channel a part of the windfall to current generations. Spreading incremental consumption generated by oil and the gas windfall equally between current and future generations is thus not optimal if future generations are expected to be richer than current generations, especially if the social welfare function contains a substantial amount of relative intergenerational inequality aversion. The best solution is to shift incremental consumption more towards current generation relatively to the future ones. Third, it is crucial that the final part of the windfall is used to reduce indebtedness, improve credit worthiness and lower interest rates. This sets in motion a process of investment and of growth and development. Effectively, the windfall is used not to build a sovereign wealth fund but to speed up the process of growth and development. Only once capital scarcity is alleviated is it optimal to direct attention to a permanentincome rule with saving in a fund. Araujo et al. (2016) also highlight that investment in 
developing economies is low due to high interest rates for borrowing if countries are heavily indebted. This study argues that for external sustainability the best policy is to channel the windfall for both debt reduction and domestic investment, and the precise amount depends on the specific features of the developing country.

Summing up, an oil and gas windfall offers a golden once-in-a-lifetime opportunity to bring consumption forward to help the currently relatively poor generations and to lower the debt burden and thereby lower the cost of borrowing, boost investment and promote growth and development. Capital-scarce, developing economies should thus use part of their windfall to invest in the domestic economy, which contrasts with the permanent-income approach that requires all oil and gas revenues to be invested abroad.

Whether Russia should be considered as a developing economy or not from the point of view of the above considerations is a moot point. Certainly, in some respects Russia is a developing economy and it has suffered restricted access to international capital markets. Despite significant investments in infrastructural projects and capital investments during 2004-2008, Russia can be viewed to a certain extent as a capitalscarce economy especially once the politically imposed restrictions on access to international financial markets took place in 2014. But Russia has already reduced its public debt and increased consumption during the first decade of 2000 (see Supplementary Appendix S.2). Moreover, Russia had already established funds for resource windfall accumulation in line with the recommendations discussed in sections 2, 4 and 5. The need for establishing a fund and channeling some of the windfall revenue towards such a fund is especially important given that Russia's windfall is very large in relationship to its public debt (van der Ploeg, Venables, 2011). That is why the permanent-income rule and policy prescriptions are relevant for Russia.

\subsection{Absorption constraints, the real exchange rate and Dutch disease}

Our analysis so far has been based on a one-sector economy. However, it is important to allow for traded and non-traded sectors to gain better understanding of the impact of a resource windfall on the economy. It is well known that if windfalls are not saved that the extra spending leads to sharp appreciations of the real exchange rate, i.e., a boost to the relative price of non-tradables, and thus to expansion of the non-tradables sector and contraction of the tradables sector (e.g., Corden and Neary,1982 ; Corden, 1984; Neary, 
1988). This is the essence of the Dutch disease. The traded sector can contract because tradables can be imported from abroad, but the non-traded sector must expand as there is no other way to satisfy the demand for non-tradables. The reallocation of labour and capital from the tradables to the non-tradables sector is incentivized by the sharp increase in the relative price of non-tradables. The real appreciation is especially large if demand and supply of non-tradables do not respond much to changes in prices and if most of the windfall is spent rather than saved.

Extending this type of analysis towards an intertemporal framework with optimal saving and spending, one can establish that it is optimal to smooth the time path of the real exchange rate to avoid big fluctuations in the sizes of the traded and non-traded sectors of the economy as well as to smooth the time path of consumption. This optimal policy provides a synthesis of the optimal management of windfalls based on the permanent income hypothesis and the literature on Dutch disease. It avoids volatile reallocations of labour and other production factors from the traded to the non-traded sector. Instead, the windfall leads to a small permanent contraction of the traded and expansion of the nontraded sector. A temporary windfall, whether it is anticipated or not, when managed by a permanent-income rule will thus lead to a modest permanent appreciation of the real exchange rate, a permanent modest contraction of the traded sector, and a permanent modest expansion of the non-traded sector and a permanent increase in private and public consumption.

A more realistic longer run analysis must also allow for absorption constraints which imply that it is not possible to rapidly increase or only do very inefficiently the production of non-tradables until investments in that sector have risen sufficiently. This can only be done after investing in the domestic infrastructure or home-grown structures such as roads, railways, hospitals, schools and the quality of the judiciary and the civil service as all of these help to boost the productive capacity of non-tradables. It can then be shown that the real exchange rate must appreciate to signal and gradually boost investment in domestic home-grown structures so that with time a more efficient spending of the windfall can take place (cf. van der Ploeg and Venables, 2013). The real exchange rate thus has to appreciate to indicate shortages of non-traded goods and incentivize markets to shift resources to the production of capital for the non-tradables sector. This relies on the assumption that the non-traded sector is intensive in structures 
and the traded sector is intensive in labour. Over time the absorption capacity of the economy is thus improved. As more labour and other production factors are shifted from tradables and non-tradables production, the relative price of non-tradables falls back to its pre-windfall level.

As productive capacity of non-tradables expands a greater proportion of the windfall can be spent on non-tradables. Such an "investing to invest" strategy requires a country to temporarily park some of the windfall revenue in an investment fund until productive capacity has expanded sufficiently to spend the windfall in an efficient manner (Venables, 2016). Of course, absorption constraints and "investing to invest" policies are important for countries such as Russia. Short-run appreciations of the real exchange rate may thus be required to alleviate short-run absorption constraints.

\subsection{Short-run issues and role for exchange rate and monetary policies}

If the economy is at full employment and prices and wages quickly adjust to clear the labour market, the nominal exchange rate does not matter. Since oil and gas revenue management is a medium to long term issue, this may not be such a bad assumption. That is why we have focused in section 6.2 mostly on the real rather than the nominal exchange rate. However, short-run issues do matter if there is wage and price rigidity, especially if oil and gas prices crash. The optimal response for oil- and gas-rich economies is then to have a quick depreciation of the currency as wages and prices are sluggish and cannot fall quickly to adjust to the lower wealth of the nation. So what happened in Russia?

From the late 1990s till the early 2000s the central bank's aim was to reduce public debt and accumulate foreign reserves to prevent the currency from appreciating (i.e., by selling rubles in exchange for foreign currency assets). As the debt was curbed and resource revenues started to flow into the economy (since 2004), Russia's central bank pegged the nominal exchange rate. The oil price crashed from $\$ 134$ per barrel in June 2008 to $\$ 43$ per barrel in December 2008. Thus from the beginning of 2009 till 2011 the inflow of dollars into the economy fell drastically and the ruble started to depreciate. From 2009 Russia's central bank kept the nominal exchange rate within a specific corridor by spending significant reserves to defend the currency. The oil price partially recovered in April 2011 to $\$ 123$ per barrel. The monetary authorities therefore decided 
to shift towards a floating exchange rate regime and inflation targeting. This process lasted for 5 years and was speeded up in 2014 after the sanctions that were imposed and the oil price crash. In December of 2014 the exchange rate became fully floating. Relative to other oil- and gas-rich countries Russia thus did not respond too badly as the float implied a quick depreciation of the ruble which made the adjustment to lower oil and gas prices easier.

This account of Russia's monetary policy makes clear that a short-run analysis of monetary and fiscal policies is important. One often sees that monetary authorities have to step in when fiscal authorities fail to use fiscal policy to smooth consumption and the real exchange rate. This means that during a windfall or an oil price hike the central bank accumulates foreign reserves, which can be viewed as a shadow sovereign wealth fund. During an oil price crash the accumulated reserves can then be used to smooth things out. In contrast to Russia most oil- and gas-rich countries have a nominal exchange rate peg or are part of a currency union (e.g., in Western Africa), which makes it very difficult for them to adjust to an oil price crash or discovery of reserves (e.g., Wills and van der Ploeg, 2014). Whether a country has a nominal exchange rate peg, a managed float or a full float matters, because revenue has to be converted from dollars to rubles. For example, if the central bank steps in during a crash in commodity prices to prevent rapid nominal depreciation of the currency and inflation, foreign reserves will be rapidly depleted and this may lead to a speculative attack on the currency.

An out of equilibrium story of the comparative dynamics where deviations of the home real interest rate from the world real interest rate lead to expected appreciation or depreciation of the real exchange rate is certainly important. The New Keynesian microfounded macro DSGE framework offers a general equilibrium analysis to explain the movements in the interest rate and makes output, unemployment and inflation endogenous. In such a framework the wealth effects of an anticipated resource bonanza imply that the forward-looking component of inflation suppresses output below its natural level. Interestingly, if the central bank follows a simple Taylor rule for the nominal interest rate that tightens aggressively against inflation, it actually exacerbates this recession (Wills, 2015). Since the welfare-relevant output gap in such economies depends on oil technology, the weight of on the output gap in the Taylor rule increases in the size of the oil sector (Ferrero and Seneca, 2015). With substantial spill-overs of 
oil to the rest of the economy, a crash in the oil price then warrants a cut in the nominal interest rate. This contrasts with the situation where the central bank's mandate is to stabilize CPI inflation in which case the nominal interest rate must be raised to curb the inflationary impacts of depreciation of the nominal exchange rate.

\section{Concluding remarks}

Sustainable management of oil and gas revenue requires that oil and gas assets under the ground are harnessed for future generations by saving them for future generations in an independently managed fund. The resulting permanent-income rule sustains a permanent boost to public spending or a permanent cut in the non-oil/gas rate. If the fiscal stance is unsustainable and the economy switches to a sustainable permanentincome rule, one can calculate how much the fiscal stance needs to be tightened. Using our benchmark estimates for projected growth of the economy and projected oil and gas revenue based, we find that Russia the permanent budget transfer resulting from oil and gas revenue is $2.9 \%$ of GDP. Unfortunately, this is less than what is currently transferred and therefore Russia needs to tighten its fiscal stance by $4.6 \%$-points of GDP by boosting non-oil/gas revenue or cutting primary spending. ${ }^{11}$ Net assets are projected to rise to more than two times GDP by 2060 with oil and gas funds being three quarters that amount. If the present fiscal stance is continued until 2025 and the implementation of a sustainable permanent-income rule is delayed by 10 years, the permanent transfer resulting from oil and gas revenues is $2.1 \%$ of GDP. The permanent fiscal stance eventually needs to be tightened by a further $0.9 \%$-point of GDP. As a result, net assets rise to only 1.7 instead of 2.2 times GDP by 2060. These required adjustments show that the historical and current fiscal stance of Russia is wholly unsustainable. Implementing the Norwegian bird-in-hand rule in Russia requires even tougher immediate tightening of the fiscal stance by 7\%-points of GDP, but not so in the long run. In view of the volatile fiscal stance under this rule and its potential adverse effects on the Russian economy, we do not advocate the bird-in-hand rule.

\footnotetext{
${ }^{11}$ If we base our calculations on statistics from the Federal instead of the Consolidated Budget of the Russian Federation, the permanent budget transfer stays 2.9\% of GDP but the required tightening of the fiscal stance is $4 \%$ - instead of $4.6 \%$-points of GDP.
} 
If oil and gas prices bounce back or new oil and gas discoveries lead to a boost of revenue by $50 \%$, the permanent transfer from oil and gas revenue to the general government budget is $4.3 \%$ instead of $2.9 \%$ of GDP. Consequently, the fiscal stance only needs to be tightened by $3.2 \%$ - instead of 4.6\%-points of GDP, net assets will grow to $285 \%$ of GDP by 2060 , and oil and gas funds will grow to $214 \%$ of GDP. However, if Russia commits to the Paris agreement of limiting global warming to 2 degrees Celsius and thus locks up of $19 \%$ its oil and 59\% of its gas reserves, the permanent transfer to the general government budget from oil and gas revenues will be only $2.0 \%$ of GDP and the required fiscal tightening is 5.5\%-points of GDP. Net assets will rise to only $159 \%$ of GDP in 2040 compared to about $218 \%$ of GDP in 2060 under the benchmark scenario.

Although our calculations are merely illustrative, we hope our analysis highlights the importance of a sound fiscal policy based on the permanent-income rule and the need for fiscal tightening of Russia's fiscal position even if oil and gas price bounce back substantially. This need is stronger if Russia credibly commits to curb global warming to 2 degrees Celsius and locks up substantial parts of its oil and gas reserves. Of course, to the extent that our figures for oil and gas revenue are an under-estimate, the required adjustment of the fiscal stance needs to be less severe.

To the extent that Russia suffers from capital scarcity, it is important to use the windfall to improve credit worthiness and boost domestic investments to its optimal level before reverting to fund management and a permanent-income rule. And to the extent that Russia experiences absorption constraints, it is important to channel some of the funds to a parking fund unless the productive capacity of the economy has improved enough to absorb the windfall efficiently.

We close with two important caveats about political economy. The first one concerns the time path of oil and gas production. We have treated it as exogenous, but clearly it is endogenous. Key is the question whether a country like Russia (not an OPEC country) should or should not back an OPEC agreement to cut the supply of oil and gas to keep prices high (e.g., if Iran pumps more oil and gas). Russia backed the recent Algiers agreement and fully implements it (consequently oil prices were pushed up from below $\$ 50$ to more than $\$ 55$ per barrel). Given that the elasticity of demand for oil and gas is 
less than unity, such backing reduces revenue today and is thus risky from a fiscal stance point of view, but of course will lead to more cash in the future as more oil and gas is left in the ground. Since Russian (like Saudi) policy makers face a large population which needs to be kept satisfied, cutting production may make it unaffordable.

The second caveat is that implementation of the permanent-income rule may be frustrated by political obstacles. Politicians with a partisan bias in spending and faced with the prospect of being removed from office by rival political factions have little appetite to invest in a fund with liquid assets that can easily be raided by its political opponents. Instead, they prefer to put the windfall revenue in partisan illiquid and irreversible investment projects which cannot be raided. Furthermore, impatient and inconsistent politicians prefer spending hikes and tax cuts now and regret them when the time comes to cut the budget and raise taxes to repay accumulated debt plus interest as the theory of hyperbolic discounting would suggest (Laibson, 1997).

Although it is beyond the scope of the present paper, future work should be directed towards the political economy of oil and gas production and windfall management.

\section{Acknowledgements}

We acknowledge support from the St. Petersburg State University Laboratory "Economic performance and the environment" and the BP funded Oxford Centre for the Analysis of Resource Rich Economies. We are grateful for the helpful comments of Dina Lvova, Nadezhda Pakhomova and Partha Sen.

\section{References}

Agénor P.-R. (2016). Optimal fiscal management of commodity price shocks, Journal of Development Economics, 122, pp.183-196.

Araujo J.D, Li B.G., M. Poplawski-Ribeiro and L.-F. Zanna (2016). Current account norms in natural resource rich and capital scarce economies, Journal of Development Economics, 120, pp. 144-156.

Barnett, S. and R. Ossowski (2003). Operational aspects of fiscal policy in oilproducing countries, in J. Davis, R. Ossowski and A. Fedelino (eds.), Fiscal 
Policy Formulation and Implementation in Oil-Producing Countries, International Monetary Fund, Washington, D.C.

Barro, R.J. (1979). On the determination of the public debt, Journal of Political Economy, 87, 5, 940-971.

Bornhorst, F., S. Gupta and J. Thornton (2009). Natural resource endowments and the domestic revenue effort, European Journal of Political Economy, 25, 4, 439446.

BP(2016). Statistical Indicators, BP, London.

Bremer, T.S van den and F. van der Ploeg (2013), Managing and harnessing volatile oil windfalls, IMF Economic Review, 61, 1, 131-167.

Bremer, T.S. van den and F. van der Ploeg (2016). Saving Alberta's resource revenues: role of intergenerational and liquidity funds, Energy Policy, forthcoming.

Carbon Tracker and Grantham Research Institute (2013). Unburnable Carbon 2013: Wasted Capital and Stranded Assets, London.

Collier, P., F. van der Ploeg, M. Spence, and A.J. Venables (2010). Managing resource revenues in developing economies, IMF Staff Papers, 57, 1, 84-118.

Corden, W.M. (1984). Booming sector and Dutch disease economics: survey and consolidation, Oxford Economic Papers, 36, 3, 359-380.

Corden, W.M. and J.P. Neary (1982). Booming sector and de-industrialisation in a small open economy, Economic Journal, 92, 368, 825-848.,

Davis, J., R. Ossowski, J. Daniel and S. Barnett (2002). Stabilization and Savings Funds for Non-Renewable Resources: Experience and Fiscal Policy Implications, IMF Occasional Paper No. 205, IMF, Washington, D.C.

Ermakova E. (2012) Accumulation of hydrocarbon revenues in Russia: tax issues, Financial Analytics: Problems and Solutions, 9 (99), 2-12

Ferrero, A. and M. Seneca (2015). Notes on the underground: monetary policy in resource-rich economies, Working Paper 2015/02, Norges Bank, Oslo, Norway.

Ghosh, A.R., J.I. Kim, E.G. Mendoza, J.D. Ostry and M.S. Qureshi (2011). Fiscal fatigue, fiscal space and debt sustainability in advanced economies, Working Paper No. 16782, NBER, Cambridge, Mass.

Gonzalo, J., (1994). Five alternative methods of estimating long-run equilibrium relationships, Journal of Econometrics, 60, 1-2, 203-233

Gurvich E., E. Vakulenko and P. Krivenko (2009) Cyclic properties of fiscal policy in oil-rich countries, Voprosy Ekonomiki, 2, 51-70.

Gurvich E. (2010) Oil and gas rents in Russian economics, Voprosy Ekonomiki, 11, 424.

Gurvich E. and A. Kudrin (2015) A growth model for Russian economy, Russian Journal of Economics, 1, 1, 30-54

Hamilton, J.D. (2009). Understanding crude oil prices, Energy Journal, 30, 2, 179-206. 
Harding, T. and F. van der Ploeg (2013). Official forecasts and management of oil windfalls, International Tax and Public Finance, 20, 5, 827-866.

Hartwick, J.M. (1997). Intergenerational equity and the investment of rents from exhaustible resources, American Economic Review, 67, 972-974.

Helm, D. (2016). The future of fossil fuels - is it the end?, Oxford Review of Economic Policy, 32, 2, 191-205.

Helm, D. (2017). Burn Out. The Endgame for Fossil Fuels, Yale University Press, New Haven.

IFSWF (2015). Sovereign Wealth Fund Annual Report 2015, International Forum of Sovereign Wealth Funds, United Kingdom. Available on the Internet: http://www.ifswf.org/sites/default/files/Bocconi\%20SIL\%202016\%20Report.pdf

Laibson, D. (1997). Golden eggs and hyperbolic discounting, Quarterly Journal of Economics, 62, 2, 443-477.

Leigh, D. And J.-P. Olters (2006). Natural resource depletion, habit formation, and sustainable fiscal policy: Lessons from Gabon, IMF Working Paper 06/193, International Monetary Fund, Washington, D.C.

McGlade and Ekins (2015). The geographical distribution of fossil fuels unused when limiting global warming to $2^{\circ} \mathrm{C}$, Nature, $517,187-190$.

Medas, P. and D. Zakharova (2009). A primer on fiscal analysis in oil-producing countries, IMF Working Paper 09/56, International Monetary Fund, Washington, D.C.

Mendoza, E.G. and J.D. Ostry (2008). International evidence on fiscal solvency: is fiscal policy "responsible"?, Journal of Monetary Economics, 55, 6, 1081-1093.

Ministry of Finance of Russian Federation (2016). The volume of Reserve Fund in 2015, The volume of the National Welfare Fund in 2015. Available on the Internet: http://minfin.ru/ru/perfomance/reservefund/statistics/balances/ and http://minfin.ru/ru/perfomance/nationalwealthfund/statistics/balances/

Naumow, A. and G. Toews (2015). The relationship between oil price and costs in the oil industry, The Energy Journal, 36, Adelman special issue.

Neary, P. (1988). Determinants of the equilibrium real exchange rate, American Economic Review, 78, 1, 210-215.

Olters, J.-P. (2007). Old curses, new approaches? Fiscal benchmarks for oil-producing countries in sub-Saharan Africa, IMF Working Paper 07/107, International Monetary Fund, Washington, D.C.

Ossowski, R., M. Villafuerte, P.A. Medas and Th. Tomas (2008). Managing the Oil Revenue Boom: The Role of Fiscal Institutions, Occasional Paper 260, International Monetary Fund, Washington, D.C.

Ploeg, F. van der (2016). Fossil fuel producers under threat, Oxford Review of Economic Policy, 32, 2, 206-222. 
Ploeg, F. van der and A. J. Venables (2011). Harnessing windfall revenue: optimal policy for resource-rich developing economies, Economic Journal, 121, 551, 130.

Ploeg, F. van der and A.J. Venables (2012). Natural resource wealth: the challenge of managing a windfall, Annual Reviews in Economics, 4, 315-337.

Ploeg, F. van der and A.J. Venables (2013). Absorbing a windfall of foreign exchange, Journal of Development Economics, 103, 229-243.

Stroebel, J. and A. van Benthem (2013). Resource extraction contracts under threat of expropriation: theory and evidence, Review of Economics and Statistics, 95, 5, 1622-1639.

Venables, A.J. (2016). Using natural resources for development: why has it proven so difficult, Journal of Economic Perspectives, 30, 1, 161-184.

Wills, S. (2015). Optimal monetary responses to news of an oil discovery, Research paper 121, OXCARRE, Department of Economics, University of Oxford.

Wills, S. and F. van der Ploeg (2014). Why do so many oil exporters peg their currency? Foreign reserves as a de-facto sovereign wealth fund, IMF conference proceedings: Macroeconomic Challenges facing Low Income Countries, Washington, D.C.

Appendix A: Data

\begin{tabular}{|c|c|c|c|c|c|c|}
\hline Var. & Years & Definition & Calculated & Publication & Institution & URL \\
\hline$a_{t}$ & $\begin{array}{l}2005- \\
2015 \\
\end{array}$ & $\begin{array}{l}\text { Net assets in } \\
\text { year } t\end{array}$ & $\begin{array}{l}a_{t} \\
=b_{t}+f_{t}\end{array}$ & & & \\
\hline$b_{t}$ & $\begin{array}{l}2005- \\
2015\end{array}$ & $\begin{array}{l}\text { Other net } \\
\text { assets in year } t\end{array}$ & $\begin{array}{l}\text { Gross assets } \\
\text { - Gross } \\
\text { liabilities }\end{array}$ & $\begin{array}{l}\text { Gross assets are taken from the } \\
\text { Balance Sheet of the } \\
\text { Consolidated Budget of RF; } \\
\text { Gross liabilities calculated } \\
\text { from the data of the Ministry } \\
\text { of Finance as as sum of } \\
\text { External Governmental Debt, } \\
\text { Internal Governmental Debt } \\
\text { and the Debt of Federation } \\
\text { Entities }\end{array}$ & $\begin{array}{l}\text { Ministry of } \\
\text { Finance of } \\
\text { Russian } \\
\text { Federation; } \\
\text { Federal } \\
\text { Treasury of } \\
\text { Russian } \\
\text { Federation; }\end{array}$ & $\begin{array}{l}\underline{\text { http://minfin.ru/ru/ }} \\
\text { perfomance/public } \\
\text { debt/index.php } \\
\text { http://www.roskazn } \\
\text { a.ru/ispolnenie- } \\
\text { byudzhetov/konsoli } \\
\text { dirovannyj- } \\
\text { byudzhet/ }\end{array}$ \\
\hline$D_{I S G A S_{t}}$ & $\begin{array}{l}1998- \\
2015\end{array}$ & $\begin{array}{l}\text { new } \\
\text { discoveries of } \\
\text { gas in year } t, \\
\text { measured in } \\
\text { thousand cubic } \\
\text { metres }\end{array}$ & $\begin{array}{l}D_{I S G A S_{t}} \\
=R G A S_{t+1} \\
-R G A S_{t} \\
+G A S_{t}\end{array}$ & & & \\
\hline $\mathrm{DISOIL}_{t}$ & $\begin{array}{l}1998- \\
2015\end{array}$ & $\begin{array}{l}\text { new } \\
\text { discoveries of } \\
\text { oil in year } t \text {, } \\
\text { measured in } \\
\text { barrels of oil }\end{array}$ & $\begin{array}{l}\text { DISOIL }_{t} \\
=\text { ROIL }_{t+1} \\
- \text { ROIL }_{t} \\
+ \text { OIL L }_{t}\end{array}$ & & & \\
\hline$f_{t}$ & $\begin{array}{l}2005- \\
2007\end{array}$ & $\begin{array}{l}\text { Oil and gas } \\
\text { funds in year } t\end{array}$ & $\begin{array}{l}\text { The } \\
\text { Stabilizatio } \\
\text { n Fund }\end{array}$ & $\begin{array}{l}\text { Accounts for oil and gas } \\
\text { revenues of the Federal } \\
\text { Treasury RF in the Central } \\
\text { Bank RF; } \\
\text { The Ministry of Finance RF } \\
\text { statistical reports; }\end{array}$ & $\begin{array}{l}\text { Federal } \\
\text { Treasury of } \\
\text { Russian } \\
\text { Federation; } \\
\text { Ministry of } \\
\text { Finance of } \\
\text { Russian } \\
\text { Federation }\end{array}$ & $\begin{array}{l}\frac{\text { http://www.roskazn }}{\text { a.ru/finansovye- }} \\
\underline{\text { operacii/svedeniya- }} \\
\frac{\text { o-dvizhenii- }}{\underline{\text { sredstv-po- }}} \\
\underline{\text { schetam/ }} \\
\underline{\text { http://minfin.ru/ru/ }} \\
\text { perfomance/reserve } \\
\underline{\text { fund/index.php }} \\
\underline{\text { http://minfin.ru/ru/ }}\end{array}$ \\
\hline
\end{tabular}




\begin{tabular}{|c|c|c|c|c|c|c|}
\hline & & & & & & $\begin{array}{l}\text { perfomance/nationa } \\
\text { lwealthfund/index. } \\
\text { php }\end{array}$ \\
\hline & $\begin{array}{l}2008- \\
2015\end{array}$ & $\begin{array}{l}\text { Oil and gas } \\
\text { funds in year } t\end{array}$ & $\begin{array}{l}\text { The } \\
\text { Reserve } \\
\text { Fund; The } \\
\text { National } \\
\text { Welfare } \\
\text { Fund }\end{array}$ & $\begin{array}{l}\text { Accounts for oil and gas } \\
\text { revenues of the Federal } \\
\text { Treasury RF in the Central } \\
\text { Bank RF; } \\
\text { The Ministry of Finance RF } \\
\text { statistical reports; }\end{array}$ & $\begin{array}{l}\text { Federal } \\
\text { Treasury of } \\
\text { Russian } \\
\text { Federation; } \\
\text { Ministry of } \\
\text { Finance of } \\
\text { Russian } \\
\text { Federation }\end{array}$ & $\begin{array}{l}\text { http://www.roskazn } \\
\text { a.ru/finansovye- } \\
\text { operacii/svedeniya- } \\
\text { o-dvizhenii- } \\
\underline{\text { sredstv-po- }} \\
\underline{\text { schetam/ }} \\
\text { http://minfin.ru/ru/ } \\
\text { perfomance/reserve } \\
\text { fund/index.php } \\
\text { http://minfin.ru/ru/ } \\
\text { perfomance/nationa } \\
\text { lwealthfund/index. } \\
\text { php }\end{array}$ \\
\hline$\overline{g t}$ & $\begin{array}{l}2005- \\
2015\end{array}$ & $\begin{array}{l}\text { The general } \\
\text { government } \\
\text { spending in } \\
\text { year } t\end{array}$ & & $\begin{array}{l}\text { As reported in the } \\
\text { Consolidated Budget of } \\
\text { Russian Federation }\end{array}$ & $\begin{array}{l}\text { Federal } \\
\text { Treasury of } \\
\text { Russian } \\
\text { Federation }\end{array}$ & $\begin{array}{l}\text { http://www.roskazn } \\
\text { a.ru/ispolnenie- } \\
\text { byudzhetov/konsoli } \\
\text { dirovannyj- } \\
\text { byudzhet// }\end{array}$ \\
\hline$G A S_{t}$ & $\begin{array}{l}1998- \\
2015\end{array}$ & $\begin{array}{l}\text { gas extraction } \\
\text { during year } t \text {, } \\
\text { measured in } \\
\text { thousand cubic } \\
\text { metres }\end{array}$ & & $\begin{array}{l}\text { BP Statistical Review of } \\
\text { World Energy } 2016\end{array}$ & BP & $\begin{array}{l}\text { http://www.bp.com } \\
\text { /content/dam/bp/pd } \\
\text { f/energy- } \\
\text { economics/statistic } \\
\text { al-review-2016/bp- } \\
\text { statistical-review- } \\
\text { of-world-energy- } \\
\text { 2016-full- } \\
\text { report.pdf }\end{array}$ \\
\hline$G D P_{t}$ & $\begin{array}{l}1998- \\
2015\end{array}$ & $\begin{array}{l}\text { GDP in } \\
\text { current prices } \\
\text { year } t, \\
\text { measured in } \\
\text { Rubles }\end{array}$ & & & $\begin{array}{l}\text { Federal State } \\
\text { Statistics } \\
\text { Service }\end{array}$ & $\begin{array}{l}\frac{\text { http://www.gks.ru/ }}{\text { wps/wcm/connect/r }} \\
\text { osstat_main/rosstat/ } \\
\text { ru/statistics/account } \\
\text { s/\# }\end{array}$ \\
\hline$\overline{n_{t}}$ & $\begin{array}{l}2005- \\
2015\end{array}$ & $\begin{array}{l}\text { share of } \\
\text { government } \\
\text { revenue from } \\
\text { oil and gas } \\
\text { production as } \\
\text { fraction of } \\
\text { GDP in year } t\end{array}$ & $\begin{array}{l}n_{t} \\
=n G A S_{t} \\
+n O I L_{t}\end{array}$ & & & \\
\hline$n G A S_{t}$ & $\begin{array}{l}2005- \\
2015\end{array}$ & $\begin{array}{l}\text { share of } \\
\text { government } \\
\text { revenue from } \\
\text { gas production } \\
\text { as fraction of } \\
\text { GDP in year } t\end{array}$ & $\begin{array}{l}\text { Severance } \\
\text { tax on gas } \\
\text { and gas } \\
\text { condensate; } \\
\text { export tax } \\
\text { on gas }\end{array}$ & $\begin{array}{l}\text { As reported in the } \\
\text { Consolidated Budget of } \\
\text { Russian Federation }\end{array}$ & $\begin{array}{l}\text { Federal } \\
\text { Treasury of } \\
\text { Russian } \\
\text { Federation }\end{array}$ & $\begin{array}{l}\text { http://www.roskazn } \\
\text { a.ru/ispolnenie- } \\
\text { byudzhetov/konsoli } \\
\text { dirovannyj- } \\
\text { byudzhet/ }\end{array}$ \\
\hline$n O I L_{t}$ & $\begin{array}{l}2005- \\
2015\end{array}$ & $\begin{array}{l}\text { share of } \\
\text { government } \\
\text { revenue from } \\
\text { oil production } \\
\text { as fraction of } \\
\text { GDP in year } t\end{array}$ & $\begin{array}{l}\text { Severance } \\
\text { tax on oil; } \\
\text { export tax } \\
\text { on oil and } \\
\text { goods } \\
\text { produced } \\
\text { from oil }\end{array}$ & $\begin{array}{l}\text { As reported in the } \\
\text { Consolidated Budget of } \\
\text { Russian Federation }\end{array}$ & $\begin{array}{l}\text { Federal } \\
\text { Treasury of } \\
\text { Russian } \\
\text { Federation }\end{array}$ & $\begin{array}{l}\text { http://www.roskazn } \\
\text { a.ru/ispolnenie- } \\
\text { byudzhetov/konsoli } \\
\text { dirovannyj- } \\
\text { byudzhet/ }\end{array}$ \\
\hline$O I L_{t}$ & $\begin{array}{l}1998- \\
2015\end{array}$ & $\begin{array}{l}\text { oil extraction } \\
\text { during year } t \text {, } \\
\text { measured in } \\
\text { barrels of oil }\end{array}$ & & $\begin{array}{l}\text { BP Statistical Review of } \\
\text { World Energy } 2016\end{array}$ & BP & $\begin{array}{l}\text { http://www.bp.com } \\
\text { /content/dam/bp/pd } \\
\text { f/energy- } \\
\text { economics/statistic } \\
\text { al-review-2016/bp- } \\
\text { statistical-review- } \\
\text { of-world-energy- } \\
\text { 2016-full- } \\
\text { report.pdf }\end{array}$ \\
\hline$p_{t}$ & $\begin{array}{l}2005- \\
2015\end{array}$ & $\begin{array}{l}\text { Primary deficit } \\
\text { in year } t\end{array}$ & $\begin{array}{l}p_{t} \\
=\tau_{t}-g_{t}\end{array}$ & & & \\
\hline$P_{t}^{G A S}$ & $\begin{array}{l}1998- \\
2015\end{array}$ & $\begin{array}{l}\text { world price of } \\
\text { oil in year } t \text {, } \\
\text { measured in } \\
\text { US dollars per } \\
\text { barrel of oil }\end{array}$ & & $\begin{array}{l}\text { BP Statistical Review of } \\
\text { World Energy } 2016\end{array}$ & BP & $\begin{array}{l}\text { http://www.bp.com } \\
\text { /content/dam/bp/pd } \\
\text { f/energy- } \\
\text { economics/statistic } \\
\text { al-review-2016/bp- } \\
\text { statistical-review- } \\
\text { of-world-energy- } \\
\text { 2016-full- } \\
\text { report.pdf }\end{array}$ \\
\hline
\end{tabular}




\begin{tabular}{|c|c|c|c|c|c|c|}
\hline$P_{t}^{\text {OIL }}$ & $\begin{array}{l}1998- \\
2015\end{array}$ & $\begin{array}{l}\text { world price of } \\
\text { oil in year } t \text {, } \\
\text { measured in } \\
\text { US dollars per } \\
\text { barrel of oil } \\
\text { (Brent) }\end{array}$ & & $\begin{array}{l}\text { BP Statistical Review of } \\
\text { World Energy } 2016\end{array}$ & BP & $\begin{array}{l}\text { http://www.bp.com } \\
\text { /content/dam/bp/pd } \\
\text { f/energy- } \\
\text { economics/statistic } \\
\text { al-review-2016/bp- } \\
\text { statistical-review- } \\
\text { of-world-energy- } \\
\text { 2016-full- } \\
\text { report.pdf }\end{array}$ \\
\hline$R G A S_{t}$ & $\begin{array}{l}1998- \\
2015\end{array}$ & $\begin{array}{l}\text { reserves at } \\
\text { beginning of } \\
\text { year } t \\
\text { measured in } \\
\text { cubic metres }\end{array}$ & & $\begin{array}{l}\text { BP Statistical Review of } \\
\text { World Energy } 2016\end{array}$ & BP & $\begin{array}{l}\text { http://www.bp.com } \\
\text { /content/dam/bp/pd } \\
\text { f/energy- } \\
\text { economics/statistic } \\
\text { al-review-2016/bp- } \\
\text { statistical-review- } \\
\text { of-world-energy- } \\
\text { 2016-full- } \\
\text { report.pdf }\end{array}$ \\
\hline ROIL $_{t}$ & $\begin{array}{l}1998- \\
2015\end{array}$ & $\begin{array}{l}\text { reserves at } \\
\text { beginning of } \\
\text { year } t \\
\text { measured in } \\
\text { cubic metres }\end{array}$ & & $\begin{array}{l}\text { BP Statistical Review of } \\
\text { World Energy } 2016\end{array}$ & $\mathrm{BP}$ & $\begin{array}{l}\text { http://www.bp.com } \\
\text { /content/dam/bp/pd } \\
\text { f/energy- } \\
\text { economics/statistic } \\
\text { al-review-2016/bp- } \\
\text { statistical-review- } \\
\text { of-world-energy- } \\
\text { 2016-full- } \\
\text { report.pdf }\end{array}$ \\
\hline $\begin{array}{l}\mathrm{R} / \mathrm{P} \\
\text { ratio }\end{array}$ & $\begin{array}{l}1998- \\
2015\end{array}$ & $\begin{array}{l}\text { Reserve to } \\
\text { production } \\
\text { ratio }\end{array}$ & & $\begin{array}{l}\text { BP Statistical Review of } \\
\text { World Energy } 2016\end{array}$ & BP & $\begin{array}{l}\text { http://www.bp.com } \\
\text { /content/dam/bp/pd } \\
\text { f/energy- } \\
\text { economics/statistic } \\
\text { al-review-2016/bp- } \\
\text { statistical-review- } \\
\text { of-world-energy- } \\
\text { 2016-full- } \\
\text { report.pdf }\end{array}$ \\
\hline$\alpha^{G A S}$ & $\begin{array}{l}2005- \\
2015\end{array}$ & $\begin{array}{l}\text { Combined } \\
\text { effects of } \\
\text { government } \\
\text { take and } \\
\text { extraction }\end{array}$ & $\begin{array}{l}\text { Caculated } \\
\text { as average } \\
\text { based on } \\
\text { the data of } \\
\text { extraction } \\
\text { and } \\
\text { government } \\
\text { hydrocarbo } \\
\text { n revenue }\end{array}$ & $\begin{array}{l}\text { Government hydrocarbon } \\
\text { revenue is taken from the } \\
\text { Federal Budget of Russian } \\
\text { Federation; } \\
\text { Data of extraction is taken } \\
\text { from BP Statistical Review of } \\
\text { World Energy } 2016\end{array}$ & $\begin{array}{l}\text { BP, Federal } \\
\text { Treasury of } \\
\text { Russian } \\
\text { Federation }\end{array}$ & $\begin{array}{l}\frac{\text { http://www.bp.com }}{\text { Icontent/dam/bp/pd }} \\
\text { f/energy- } \\
\text { economics/statistic } \\
\text { al-review-2016/bp- } \\
\text { statistical-review- } \\
\text { of-world-energy- } \\
\text { 2016-full- } \\
\text { report.pdf } \\
\text { http://www.roskazn } \\
\text { a.ru/spolnenie- } \\
\text { byudzhetov/konsoli } \\
\text { dirovannyj- } \\
\text { byudzhet/ }\end{array}$ \\
\hline$\alpha^{\text {OIL }}$ & $\begin{array}{l}2005- \\
2015\end{array}$ & $\begin{array}{l}\text { Combined } \\
\text { effects of } \\
\text { government } \\
\text { take and } \\
\text { extraction }\end{array}$ & $\begin{array}{l}\text { Caculated } \\
\text { as average } \\
\text { based on } \\
\text { the data of } \\
\text { extraction } \\
\text { and } \\
\text { government } \\
\text { hydrocarbo } \\
\text { n revenue }\end{array}$ & $\begin{array}{l}\text { Data of extraction is taken } \\
\text { from BP Statistical Review of } \\
\text { World Energy 2016; } \\
\text { Government hydrocarbon } \\
\text { revenue is taken from the } \\
\text { Consolidated Budget of } \\
\text { Russian Federation; }\end{array}$ & $\begin{array}{l}\text { BP, Federal } \\
\text { Treasury of } \\
\text { Russian } \\
\text { Federation }\end{array}$ & 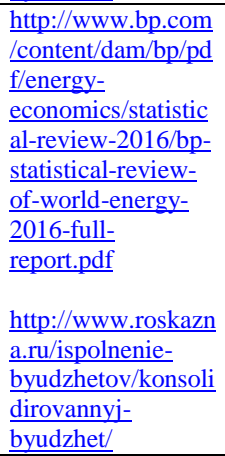 \\
\hline$\overline{\tau_{t}}$ & $\begin{array}{l}2005- \\
2015\end{array}$ & $\begin{array}{l}\text { Non-oil and } \\
\text { gas revenue in } \\
\text { year } t\end{array}$ & $\begin{array}{l}\text { Calculated } \\
\text { as } \\
\text { difference } \\
\text { between } \\
\text { General } \\
\text { Revenue } \\
\text { and oil and } \\
\text { gas revenue }\end{array}$ & $\begin{array}{l}\text { General Revenue and oil and } \\
\text { gas revenue are taken from the } \\
\text { Consolidated Budget of } \\
\text { Russian Federation }\end{array}$ & $\begin{array}{l}\text { The Federal } \\
\text { Treasury of } \\
\text { Russian } \\
\text { Federation }\end{array}$ & $\begin{array}{l}\text { http://www.roskazn } \\
\text { a.ru/ispolnenie- } \\
\text { byudzhetov/konsoli } \\
\text { dirovannyj- } \\
\text { byudzhet/ }\end{array}$ \\
\hline
\end{tabular}




\section{Appendix B: Illustrating a temporary windfall of constant oil and gas revenue}

To illustrate the differences between the permanent-income and the bird-in-hand rule, assume an unanticipated temporary windfall of the form: $n_{t}=n>0, \forall 0 \leq t<T$ and $n_{t}=0, \forall t \geq T$. It follows that under the permanent-income rule $v_{0}=f_{t}=\sum_{s=0}^{T-1}(1+r)^{-s} n=\left(\frac{(1+r)^{T}-1}{r}\right), \forall t \geq T$. The bird-in-hand rule has $f_{T+s}=(1+r-0.04)^{s} f_{T}=(1+r-0.04)^{s}\left(\frac{1-(1+r-0.04)^{T}}{0.04-r}\right) n, \forall s \geq 0$. Fund assets and thus the contribution of the windfall to the general government budget vanish eventually after the windfall has ceased under the bird-in-hand rule, but fund assets and the contribution to the budget stay constant after the windfall under the permanent-income rule.

Figure B.1 generalizes this example to an anticipated temporary windfall. It shows the time paths of $f_{t}, z_{t}$ and $f_{t}+v_{t}$ under the two rules if $r=0.02, n=0.2$ and the windfall start at time 8 and end at time 27 and the fund starts out with zero assets. We immediately notice that the contribution of the general budget and of total below- and above-ground assets is much more volatile under the bird-in-hand rule. Although up to year 52 total assets under the bird-in-hand rule are higher than under the permanentincome rule, they dwindle away to zero eventually and thus contradict the Hartwick rule. This volatility increases the welfare costs of tax distortions, so the permanentincome rule is preferred over the bird-in-hand rule.

\section{Figure B.1: Permanent-income versus bird-in-hand rules}
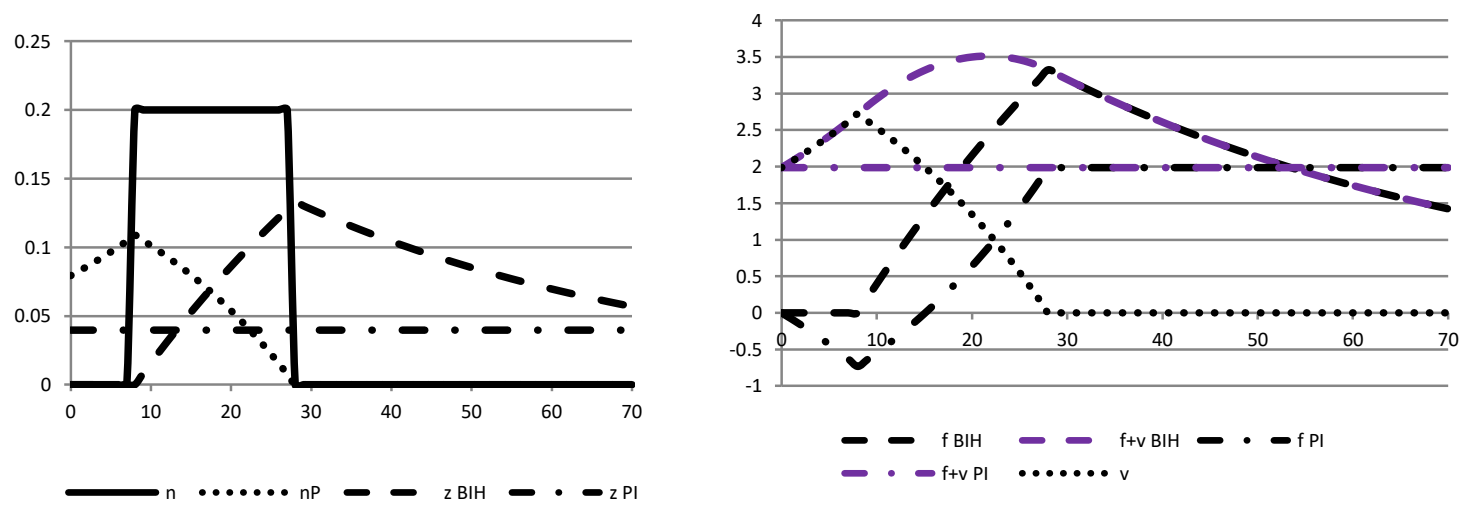
To smooth intertemporal tax distortions, the permanent-income rule prescribes to borrow during the first seven years in advance of the windfall and to save afterwards. This follows from permanent oil income rising during the anticipation period as the windfall gets closer and then falling to zero at the end of the windfall. From the end of the 20-year windfall onwards, the country acts as a rentier keeping financial SWF wealth constant. In contrast, under the permanent income rule there is no withdrawal at all during the anticipation period as this only occurs as financial wealth is accumulated in the SWF. 


\section{SUPPLEMENTARY ONLINE APPENDIX}

\section{S.1: Oil and gas extraction and revenue in Russia}

Figure S.1 shows the oil and gas reserves volume, the reserve-to-production ratio (R/P ratio) and the production volumes in Russia within the period of 1998 and 2015. There is a constant decline both in reserves and $\mathrm{R} / \mathrm{P}$ ratio as well as the constant growth in oil production. During 2000 and 2006 there was a plunge in oil reserves caused by a significant increase in oil production as a response to the rise in the world price of oil. Oil reserves briefly soared between 2007-2009 due to the discovery of new oil fields in Yamalo-Nenetskiy district and in water areas of Barentsevo sea and Karskoe sea ${ }^{12}$ before steadily decreasing and reaching its low in 2015.

\section{Figure S.1: Russian oil and gas proved reserves, $\mathrm{R} / \mathrm{P}$ ratios and production}
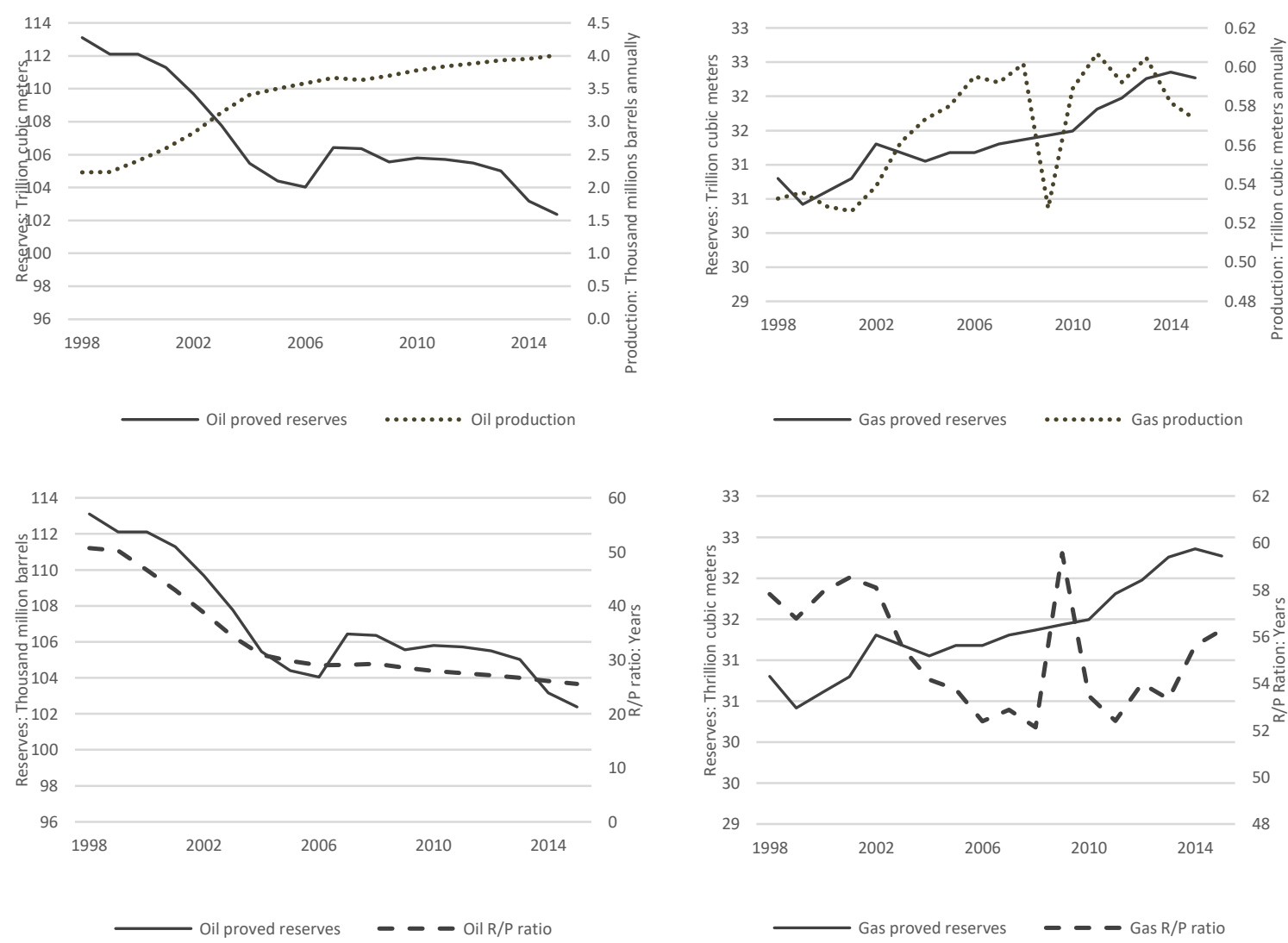

Source: BP Statistical Review of World Energy 2016

The development of gas reserves is quite different during this period. After a slight dip in 1999 the volume of gas reserves rose gradually and reaches a high in 2014 . The gas

\footnotetext{
${ }^{12}$ See Think-tank Mineral, http://www.mineral.ru/Facts/russia/131/288/index.html
} 
$\mathrm{R} / \mathrm{P}$ ratio decreases over time from 57.2 in 1998 to 52.1 in 2008 caused by the steady growth in gas production (from 0.5 to 0.6 trillion cubic meters annually). In 2008 the $\mathrm{R} / \mathrm{P}$ ratio rocketed dramatically reaching its high of 59.6 in 2009 , followed by a sharp decline to 53.1 the year after. The reason for this fluctuation was the significant dip in gas production volumes (from 0.6 to 0.52 trillion cubic meters annually) in 2009 caused by the world financial crisis. In general, beginning from 2011 we see a growing $\mathrm{R} / \mathrm{P}$ ratio and declining gas production. To sum up, oil production increases while oil reserves are gradually depleted and gas production decreases while gas reserves are growing.

The fiscal treatment of hydrocarbon rents has changed greatly by the government from 1998 till 2015. From the end of Soviet period up to 2002 taxation on natural resources was general and tax rates were fixed depending on the extracted volume of resource for each resource, including hydrocarbons. This tax was called Payment for Natural Resource Utilisation and accounts for 3.33\% from total government fiscal income in 2001 (the Government Budget of Russian Federation, 2001). The tax base included not only hydrocarbons, but other natural resources such as water and forests as well. Limiting the tax base to hydrocarbons only, tax revenue would be only $2.5 \%$ from total government fiscal income in 2001 (the Government Budget of Russian Federation, 2001). Since these revenues accruing to the government were small, most of the extra revenue resulting from a higher price of oil seemed to be channelled to oil and gas companies rather than the government.

In the beginning of 2002 the Russian Government expected oil and gas prices to rise and thus reformed the taxation of oil and gas production. The purpose of such reforms was to enable the Government to be the main recipient of the possible hydrocarbon revenues windfall. Since 2002 oil and gas revenues have been channelled to the Government through two fiscal instruments, namely severance tax and export duties. Severance tax is applied to crude oil, flammable gas and gas condensate; export duties are charged on oil, gas and goods produced from oil. Both fiscal instruments are linked to market prices of hydrocarbons, so the Government gets extra oil and gas revenues in when prices are high but bears the risk when prices are low. 
Kudrin and Gurvich (2014) estimate that the Government captures about $70 \%$ of hydrocarbon rents. This view is supported by World Bank data, albeit that the World Bank assesses the hydrocarbon rents to be higher than the Russian Government. Figure S. 2 plots both Russian oil and gas rents from World Bank data - referred to as oil rent and gas rents - and oil and gas revenue accruing to the government budget. Although the estimates differ in magnitude, fluctuations in rents follow a similar pattern.

\section{Figure S.2: Russian oil and gas flows}
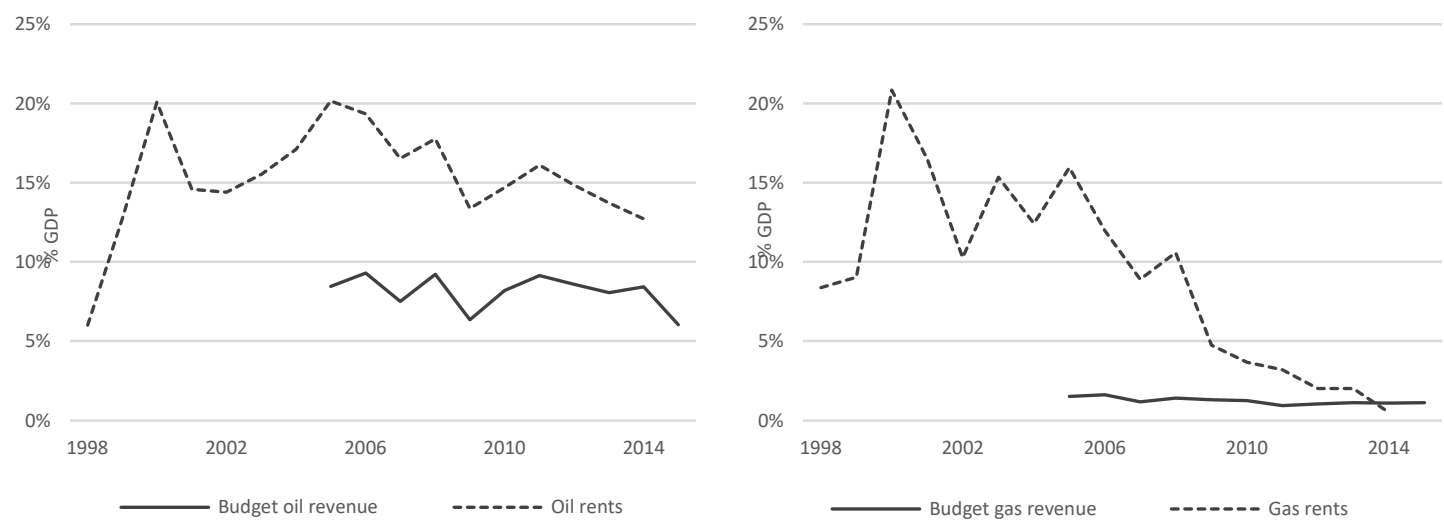

Source: the World Bank Data (dashed line) and the Government Budget of Russian Federation (solid line)

There is another approach to the estimation of oil and gas rents suggested by Gurvich (2010) and Gurvich, et al. (2009). For the period of 1999-2009 he estimated oil and gas total rents and his results are quite close to the World Banks' ones as can be been in figure S.3.

\section{Figure S.3: Oil and gas rents and government as revenues - different assessments}
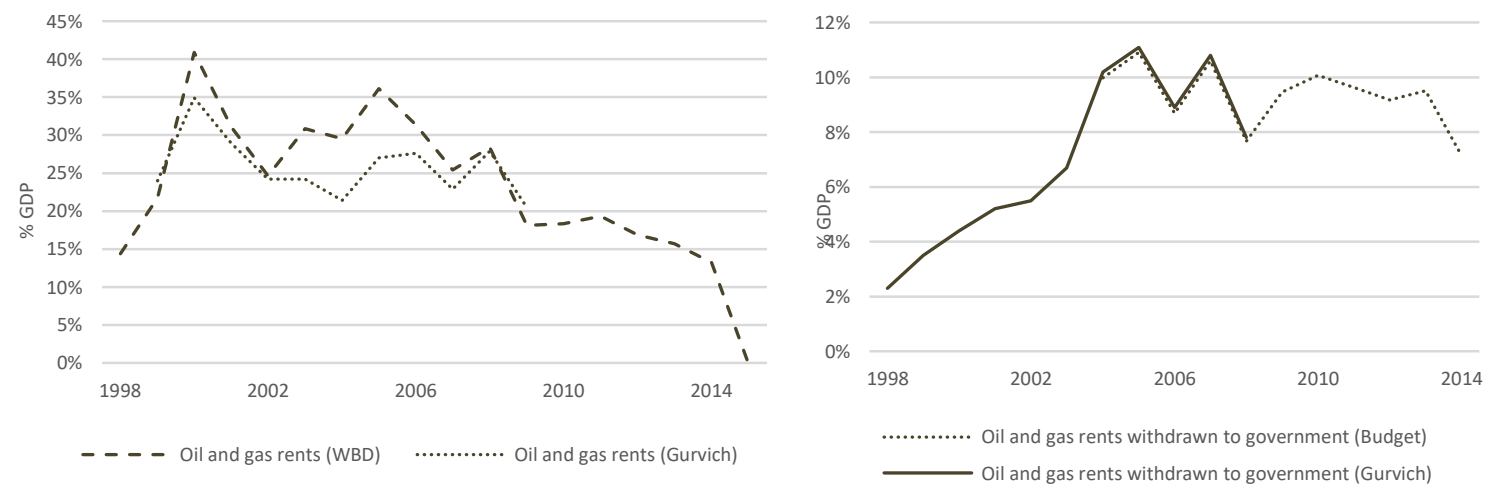

Source: World Bank Data (dashed line), Government Budget of Russian Federation (solid line), Gurvich (2011) (dotted lines) 
Gurvich calculated also that the Government lost certain parts of total hydrocarbon rents due to gaps in taxation procedures, so severance tax and export duties enabled to get up to $80 \%$ of oil rents and up to $40 \%$ of gas rents. His estimates of oil and gas rents accruing to the Government Budget were the same as those based on the Federal Budget data; see figure S.3. Hence, in view of the above, we present oil and gas budget revenue as oil and gas rents received by the Government coming from severance tax end export duties together.

\section{S.2: Past fiscal policies and the funds}

To assess the influence of oil and gas revenue (sum of severance taxes and export duties) on current government fiscal policy, we compare it with other fiscal indicators such as general governmental revenue and spending, the primary hydrocarbon deficit and the non-hydrocarbon deficit. These indicators are taken from two interrelated sources: the Federal Budget of the Russian Federation and the Consolidated Budget of the Russian Federation ${ }^{13}$. Each sources has its advantages and disadvantages, so will we discuss them in some detail.

Since oil and gas rents are only accumulated in the Federal Budget, it seems reasonable to take statistics of the important fiscal indicators from the Federal Budget. We then loose a significant part of the government revenue and spending that is not included in the Federal Budget but in the Consolidated Budget. So only relying on the Federal Budget will exaggerate the influence of oil and gas revenue on fiscal policy. We therefore prefer to take account of the statistics of the Consolidated Budget too (as the IMF does as well). Most of the strategically important oil and gas companies in Russia are owned by the Government, so the Government gets its oil and gas rents not only through severance taxes and export duties but also through indirect taxes (regional taxes) and dividends. We might thus underestimate oil and gas revenue to the government when we use the Consolidated Budget as the primary source of information. We follow the IMF and use the Consolidated budget statistics. Despite some downward bias in our oil and gas revenue estimates, they serve to illustrate the main ideas and suggestions for calculating the sustainable fiscal stance of Russia.

\footnotetext{
${ }^{13}$ The Consolidated Budget of Russian Federation is the combination of the Federal Budget and the budgets of the Federal Entities and The Municipal Entities of Russian Federation.
} 
We divide general government revenue into two parts: oil and gas revenue and other revenues. We assume that non-oil and gas revenue is independent from oil and gas revenue. This may not be completely plausible, but it will serve to illustrate our calculations. The left panel of figure S.4 represents the shares of these two parts of general government revenue as well as general government spending and smoothed general government spending (all figures are measured as the percentage of GDP). Figure S.4 also plots the primary deficit and non-hydrocarbon primary deficit.

\section{Figure S.4: Tax income, fees, hydrocarbon income, and fiscal deficit}
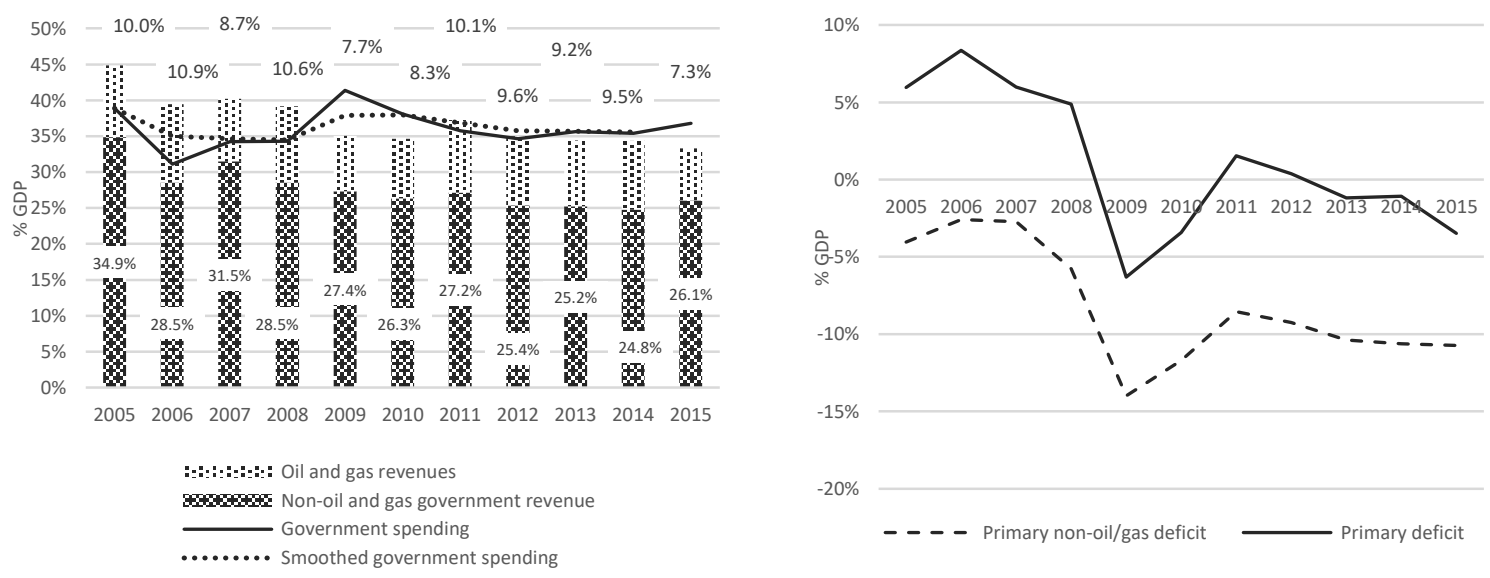

Source: Consolidated Budget of Russian Federation

Figure S.4 illustrates that general government revenue falls slowly during 2005-15. This happens primarily because of the graduate decline in the non-oil/gas part of government revenue; oil and gas revenue remains relatively stable at about 9-10\% of GDP. Oil and gas revenue accounts for approximately $25 \%$ to $30 \%$ of general government revenue. General government revenue exceeds government spending in 2005-2008. Namely these excessive amounts were reserved within oil and gas funds in that time. As a result of the world financial crisis of 2008 the government has a significant primary deficit of $6.3 \%$ (and a 14\% non-hydrocarbon deficit) in 2009 and a lower primary deficit of $3.4 \%$ of GDP (and $11.7 \%$ non-hydrocarbon deficit) in 2010. The deficit in those years is financed from the Fund. The primary deficit of the years following 2010 fluctuates around zero with government spending close to its permanent (smoothed) level of approximately $35 \%$ of GDP. Still, the non-hydrocarbon deficit during that period remains constant at about $10 \%$ of GDP. 
We now turn to a more detailed view of oil and gas revenue management during the period 2004-2015. At the beginning of 2004 the Stabilization fund of Russian Federation was constituted as a part of the Federal Budget. The Fund accumulated receipts from export taxes and severance taxes for oil above a threshold for the oil price: all oil and gas revenues with a price lower than $20 \$^{14}$ per barrel were accumulated in the Federal Budget while the rest were channelled to the Stabilization Fund. The Fund's purpose was to buffer against unfavourable oil price volatility, to cope with excess liquidity and to make economic development more stable.

The rule was that one could dip into the Fund to cover the Federal Budget deficit if the oil price was below its threshold. If the accumulated assets of the Fund exceed 500 billion of roubles, the surplus could be used for any other purpose. In 2005 and 2006 the surplus was used to curb the external government debt (3.1\% of GDP, 673.1 billion roubles in 2005 and 2.2\% of GDP, 333 billion roubles in 2006) - see figure S.5. The Fund went on growing throughout 2005-2007 and reached its high of 11.6\% GDP in 2007. During 2004-07 oil and gas revenues were partly directed to the Stabilization Fund as can be seen from figure S.5. The profit of the general budget was allocated to the Fund. Figure S.6 indicates that the amounts of hydrocarbon revenues accumulated in the Fund were about 5-6\% of GDP (approximately half of hydrocarbon revenues in total). The Stabilization Fund accounted for 522.3 billion roubles by the end of 2004, which corresponds to $3.1 \%$ of GDP.

Not only oil and gas fund accumulated oil and gas revenue. The Government made a lot of capital expenditures during 2004-08. A lot of infrastructural, social and innovative projects were launched. In particular, the Infrastructure for Winter Olympic Games Sochi-2014 had been developed since 2007. Infrastructure for APEC Summit had also been developed in Vladivostok since 2007. The construction of facilities for the Universiade-2013 had been built in Kazan in 2008; etc. The wide geographical spread of these projects shows that the development was taking place throughout the whole country. The main idea was to use the hydrocarbon windfall to develop infrastructure from the Far East to the West of the country.

\footnotetext{
${ }^{14}$ The threshold price of $\$ 20$ per barrel of oil (Urals) was valid until 31 December 2005, starting from 1 January 2006 the threshold price was increased up to \$27 per barrel of oil (Urals).
} 


\section{Figure S.6: The story of the Stabilization Fund}

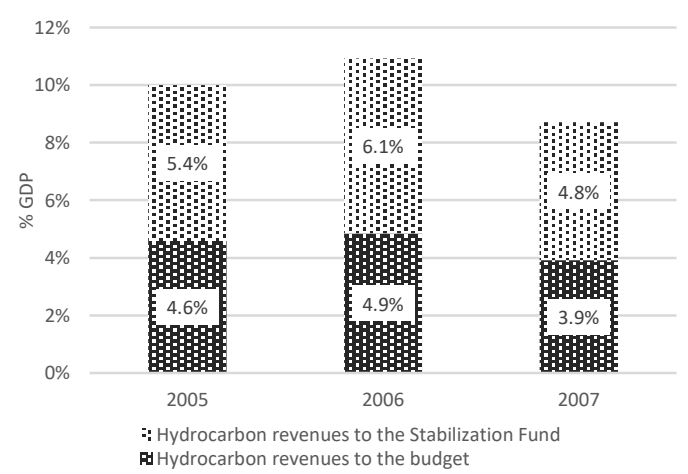

(a)

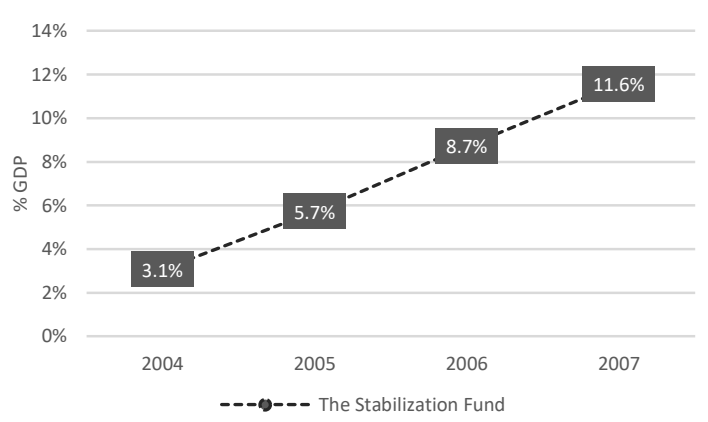

(c)

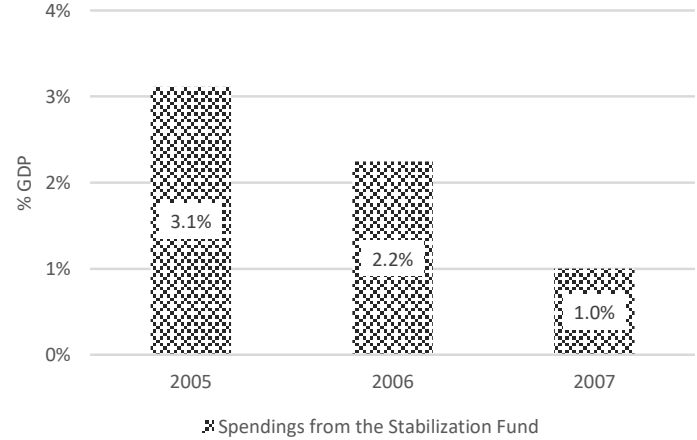

(b)

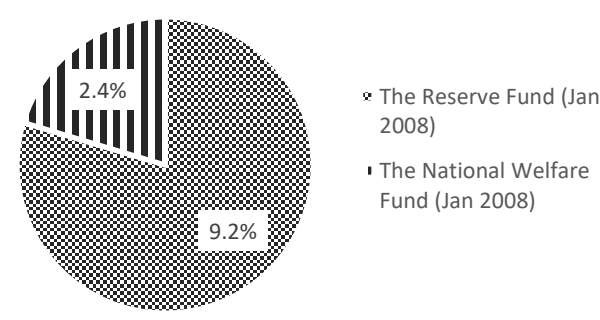

(d)

Sources: Consolidated Budget of Russian Federation, Federal Treasury of Russian Federation, Finance Ministry of Russian Federation

The budget of the Stabilization Fund was spent for financing the development institutions in the amount of 1\% of GDP (300 billion roubles) that year. In 2007 the decision was made to divide the Stabilization Fund into two separate funds: the Reserve Fund and the National Welfare Fund (see figure S.6). The aim of the Reserve Fund was to cope with volatility in resource revenues while the National Welfare Fund was to spread hydrocarbon wealth to future generations.

The incomings of the Reserve Fund and National Welfare Fund were different from those of the Stabilization Fund. The part of total oil and gas revenue received by the government was channeled to the government budget as an oil and gas transfer. As soon as the transfer amount reached its target value $3.7 \%$ of projected GDP, oil and gas revenue began to accumulate in the Reserve Fund. Once the Reserve Fund amounted to $10 \%$ of projected GDP, all remaining oil and gas revenue were channeled to the National Welfare Fund. In case the Federal Budget non-oil deficit exceeds $4.7 \%$ of 
projected GDP, there was yet another transfer different from that of the oil and gas transfer done. The sum of this second transfer was preliminary non-specified and submitted by the Government. This scheme was mainly theoretical, taking into account that the total amount of oil and gas revenue of the Government accounted for approximately $10 \%$ of GDP. In our estimates we used actual GDP while the government had used the projected one for its calculations (relying on growth of oil and gas prices on the world market).

\section{Figure S7: In- and outgoings of the Reserve Fund and National Welfare Fund}

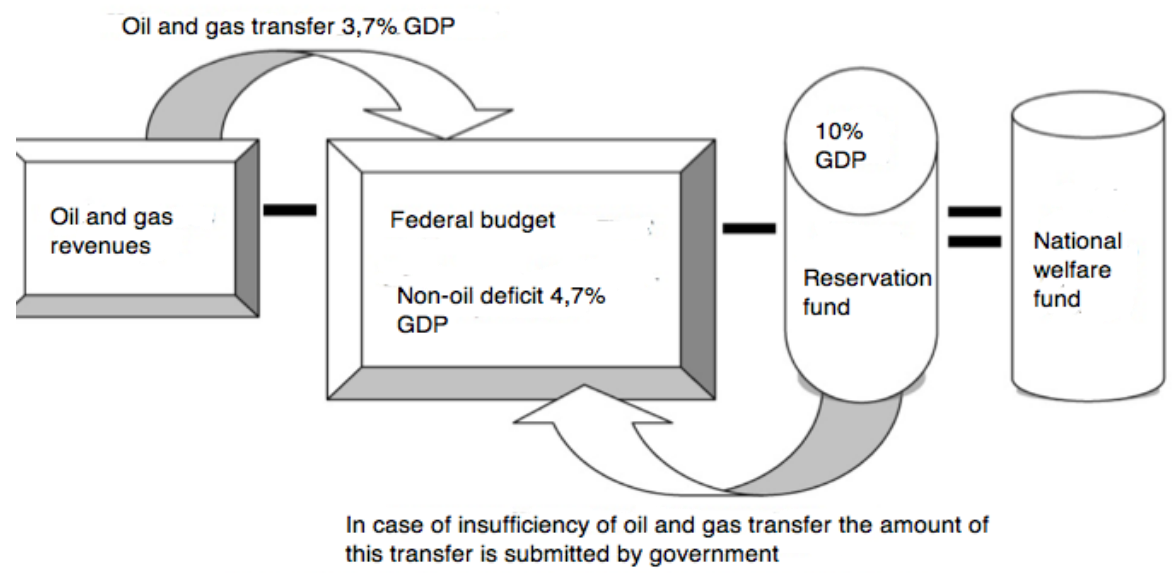

Source: Ermakova (2012)

The scheme described in figure S.7 applied in part only during 2008 and 2009. In 2008 the Federal Budget received oil and gas revenue amounting to 5.2\% of GDP (more than $50 \%$ of total hydrocarbon revenue), the Reserve Fund got oil and gas revenue corresponding to 1\% of GDP; and the National Welfare Fund was enlarged with oil and gas revenue that reached $3.9 \%$ of GDP (see figure S.8 (a)). It was the only time that the National Welfare Fund was replenished with the oil and gas revenue. In 2009 the Government transferred some part of the oil and gas revenue to the Reserve Fund. Still, it spent way more ( $8.1 \%$ of GDP, approximately $60 \%$ of Fund's reserves) to finance the budget deficit because of the world financial crisis of 2008 (see figure S.8 (c)). During 2010-11 the total amounts of oil and gas revenue was accumulated in the Federal budget with none of these sums being saved within oil and gas funds. The National Pension Extra Budgetary Fund was subsidized from the National Welfare Fund starting from 2010, but the amount of each annual subsidy was tiny (see figure S.8 (d)). 
During 2012-13 the Reserve fund was enlarged with oil and gas revenue and began to recover after 2011. This policy did not survive long, since already in 2014 all oil and gas revenue was accumulated within the Federal Budget whereupon the government transferred part of the Reserve Fund's liquidity in 2015 to reduce the budget deficit, caused by Crimea conflict of 2014 and following sanctions of 2015 .

\section{Figure S.8: The Reserve Fund and National Welfare Fund}
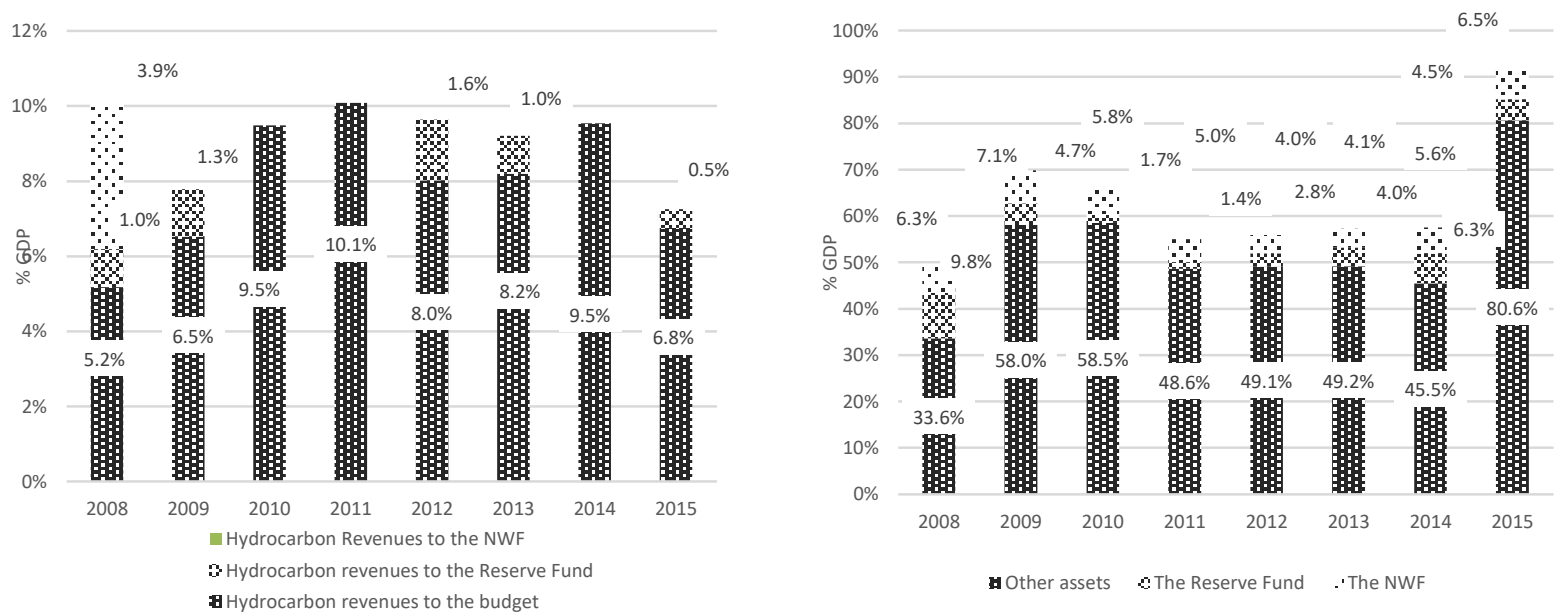

(a)

(b)

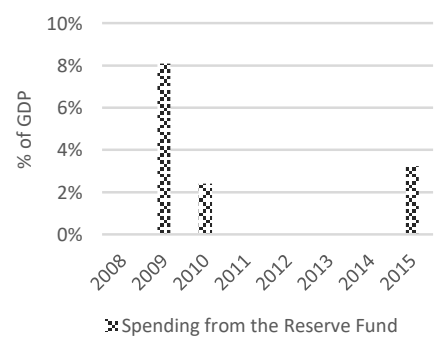

(c)

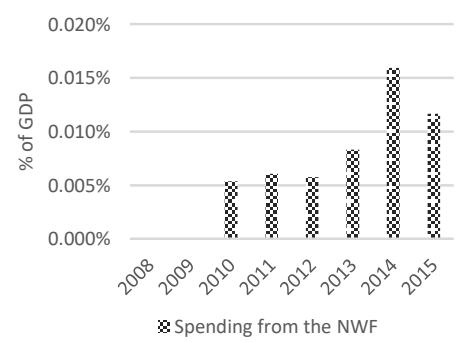

(d)

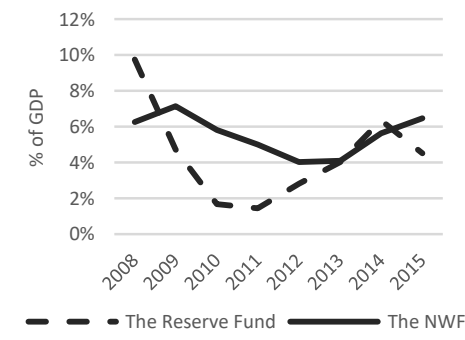

(e)

Sources: Consolidated Budget of Russian Federation, Federal Treasury of Russian Federation, Finance Ministry of Russian Federation

Figure S.8 (b) compares the size of oil and gas funds in Russia with other assets. We took into account not only financial assets, but the overall assets as stated in the Balance sheet of the Consolidated Budget for each year from 2008 to 2015. The share of oil and gas funds among the total assets fluctuated on average between $10 \%$ and $20 \%$. The maximum share of oil and gas funds was $30 \%$ and occurred in 2008. The minimum share was in 2011 after the world financial crisis of 2008 and in 2015 after the Crimea annexe in 2014. 